\title{
A dynamic analysis of financing conditions for renewable energy technologies
}

\section{Journal Article}

Author(s):

Egli, Florian Manuel (D); Steffen, Bjarne; Schmidt, Tobias (1)

Publication date:

2018

Permanent link:

https://doi.org/10.3929/ethz-b-000309636

Rights / license:

In Copyright - Non-Commercial Use Permitted

Originally published in:

Nature Energy 3(12), https://doi.org/10.1038/s41560-018-0277-y

\section{Funding acknowledgement:}

730403 - Innovation pathways, strategies and policies for the Low-Carbon Transition in Europe (SBFI) 


\title{
Energy Politics Group
}

\section{A dynamic analysis of financing conditions for renewable energy technologies}

\author{
Florian Egli, Bjarne Steffen* and Tobias S. Schmidt*
}

\author{
Published in Nature Energy \\ Please cite article as: Egli, F., Steffen, B. \& Schmidt, T.S. A \\ dynamic analysis of financing conditions for renewable energy \\ technologies. Nat Energy 3, 1084-1092 (2018). \\ https://doi.org/10.1038/s41560-018-0277-y
}

\begin{abstract}
:
Renewable energy technologies often face high upfront costs, making financing conditions highly relevant. Thus far, the dynamics of financing conditions are poorly understood. Here, we provide empirical data covering 133 representative utility-scale photovoltaic (PV) and onshore wind projects in Germany over the last 18 years. These data reveal that financing conditions have strongly improved. As drivers, we identify macroeconomic conditions (general interest rate) and experience effects within the renewable energy finance industry. For the latter, we estimate experience rates. These two effects contribute 5\% (PV) and $24 \%$ (wind) to the observed reductions in levelised costs of electricity (LCOEs). Our results imply that extant studies may overestimate technological learning and that increases in the general interest rate may increase renewable energies' LCOEs, casting doubt on the efficacy of plans to phase out policy support.
\end{abstract}

Keywords: energy finance, WACC, cost of capital, financial learning

The Energy Politics Group (EPG) within the Department of Humanities, Social, and Political Sciences of ETH Zurich investigates questions related to the governance of technological change in the energy sector. 
Keeping climate change within safe limits and achieving the goals of the Paris Agreement require fast and ample redirection of financial flows towards low-carbon technologies ${ }^{1-3}$. As approximately two-thirds of global greenhouse gas emissions stem from the energy sector ${ }^{4}$, the rapid deployment of low-carbon energy technologies, such as renewable energy technologies (RETs), is crucial for emissions reductions ${ }^{5}$. Solar photovoltaics (PVs) and wind will likely play central roles in this transition ${ }^{6}$. Importantly, as RETs are more capital intensive than fossil fuel technologies large portions of their life-cycle cost are incurred upfront and need to be financed ${ }^{7,8}$. Extant literature has established the adverse effect of high costs of capital on the levelised costs of electricity (LCOEs) for $\mathrm{RETs}^{9}, \mathrm{CO}_{2}$ abatement cost ${ }^{7,10}$ and RET deployment in integrated assessment models ${ }^{11}$. Consequently, high costs of capital are considered major obstacles to RET deployment ${ }^{12,13}$. By the same logic, low costs of capital can contribute to the observed cost reductions for solar PV and wind energy ${ }^{14-16}$. Financial markets thus have a constraining or enabling role in the low-carbon energy transition ${ }^{17-20}$.

While individual investors know their cost of capital, typically this information remains unavailable to researchers ${ }^{21,22}$, especially concerning developments over time. This paper addresses this gap, by analysing the German solar PV and onshore wind power financing market, which has a particularly long investment history ${ }^{23}$. We exploit the fact that utility-scale renewable energy investments in Germany are almost exclusively realised in project finance structures $^{24}$ (see Methods for a description), in which the costs of capital reveal unbiased information about the underlying investment projects and technologies ${ }^{25}$. We compile data on the financing conditions of 133 representative utility-scale renewable energy projects, undertaken between 2000 and 2017, to establish the temporal dynamics of costs of capital for solar PV and wind onshore. The project data is provided by leading renewable energy investors, covering lead arrangers responsible for $85 \%$ of the solar PV and $80 \%$ of the wind onshore investment sums between 2000 and 2017 (see Supplementary Figure 1). We proceed in four steps. First, using this project data, we depict the cost of capital and its components and analyse the changes over time. Second, we use qualitative insights from in-depth interviews with 41 investment professionals to identify the drivers of the observed changes in 
financing conditions. Third, we quantify an experience effect within the renewable energy finance industry, leading to lower costs of capital. Fourth, we quantify the effect of the observed changes in costs of capital on LCOEs. The methods are structured along the same four steps.

We find that the cost of capital (CoC) declined by $69 \%$ for solar PV and by $58 \%$ for wind onshore projects between the early period of the RET finance industry (2000-2005) and 2017. For both technologies, the cost of debt decreased more than the cost of equity. Focusing on the cost of debt, we identify and estimate a financing experience curve. For each doubling of cumulative investment, the debt margins (see Supplementary Table 1 for definitions of financial terms) decreased by $11 \%$ for both technologies. During the same time, we observe a decline in the general interest rate resulting in lower costs of capital that had a substantial effect on the economic attractiveness of RETs. Finally, we estimate that $41 \%$ of total solar PV LCOE reductions and 40\% of wind onshore LCOE reductions between 2000-2005 and 2017 were due to lower financing costs. These result from three effects: lower capital expenditures (CAPEX) to be financed (strongest effect for solar PV), lower general interest rate (strongest effect for wind onshore), and financing experience. We conclude with implications for researchers and policymakers.

\section{Changes in financing conditions}

In the first step, we analyse the temporal dynamics of the $\mathrm{CoC}$ and its components (see Methods). Figure 1 displays the cost of debt, the cost of equity and the $\mathrm{CoC}$ for all projects in our dataset. Both solar PV and wind onshore projects experienced substantial decreases in costs of capital. While some variance in $\mathrm{CoC}$ is normal due to slightly different project conditions, the data shows a clear decrease in the lower bound for cost of debt and cost of equity over time. The lower bound of cost of debt dropped from around $5 \%$ to less than $0.5 \%$ for both technologies. Lower bound equity returns fell from around $10 \%$ to below $4 \%$. 


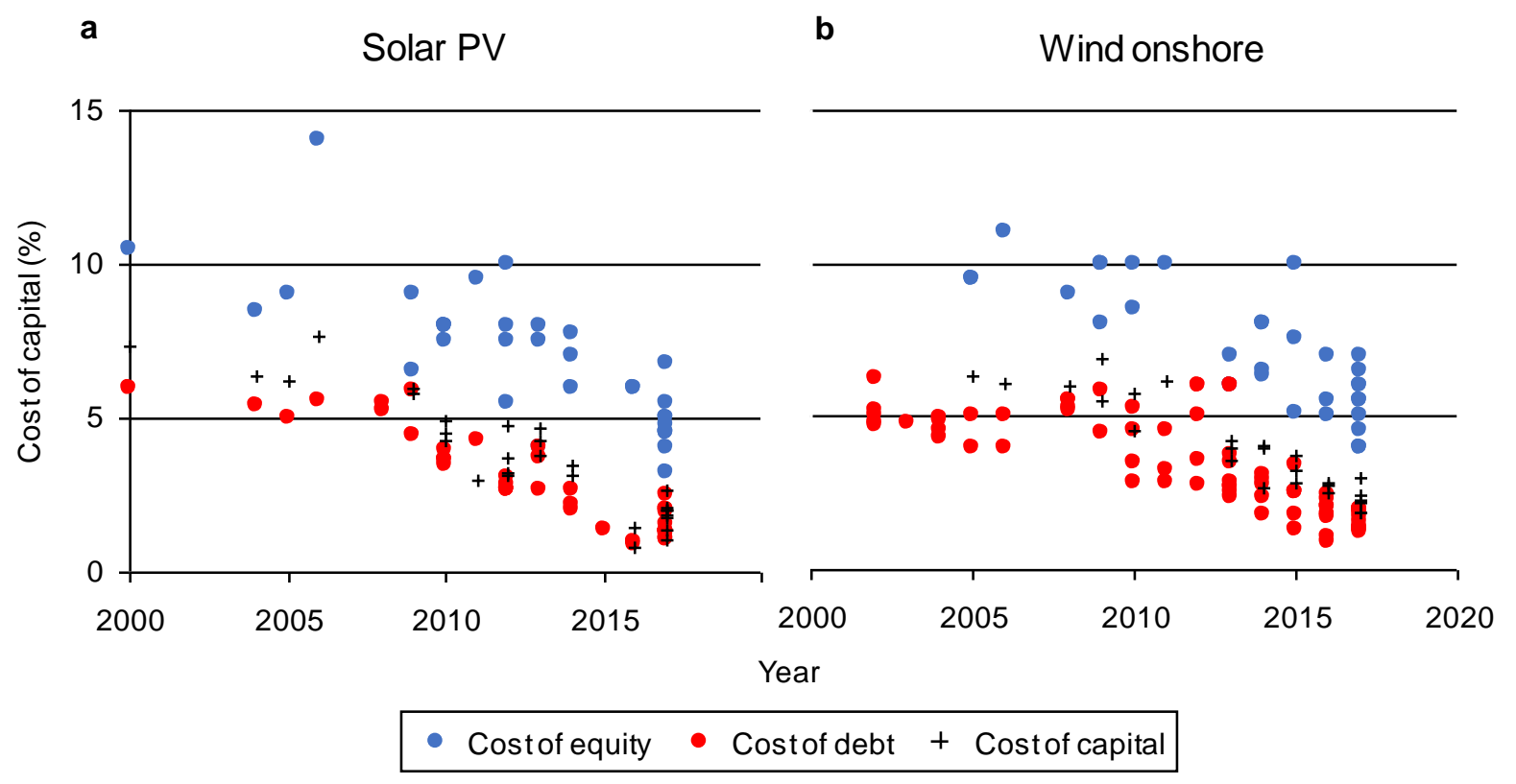

Figure 1: Costs of capital over time. Cost of debt, cost of equity and average (by project) CoC in Germany for (a) 43 solar PV and (b) 78 wind onshore projects between 2000 and 2017 ( $N=121)$. We show CoC numbers only for projects where cost of debt and cost of equity, as well as capital structure (leverage), are known (29 solar PV and 26 wind onshore projects).

Figure 2 draws on the same data as Figure 1 to calculate the average across projects and compares the early period of the RET finance industry (2000-2005) to 2017. It first shows that the cost of debt decreased more than the cost of equity in relative terms and that decreases in both components were more pronounced for solar PV than for wind onshore. However, the project $\mathrm{CoC}$ also depends on the leverage and the corporate tax rate. Leverage denotes the share of debt of the total investment sum (see Methods). Because equity bears the first project losses, a higher leverage is an indication for lower project risk. For both technologies, the leverage increased, reaching over 80\% debt financing in 2017 (see Supplementary Figure 2). During this period, the German corporate tax rate decreased from $41 \%$ to $30 \%$, resulting in relatively higher costs of debt as interest rate payments are deductible from taxable revenues.

Figure $2 \mathrm{c}$ and $2 \mathrm{~d}$ summarize the resulting after-tax $\mathrm{CoC}$. The $\mathrm{CoC}$ in 2017 were in the range of $1.6 \%$ (solar PV) to $1.9 \%$ (wind onshore), corresponding to a low-risk corporate bond of a financial service firm $(B B+\text { to } B B B)^{26}$. Stated differently, CoC declined by over two-thirds $(3.5 \%$ points) for solar PV projects and more than half (2.6\% points) for wind onshore projects. While 
the cost of capital for solar PV projects in 2000-2005 was higher than for wind onshore projects, the former had a lower cost of capital than the latter in 2017. Similar trends were observed for additional financial indicators, such as loan tenors and debt service coverage ratios (see Supplementary Figure 2). Over our study period, the duration of the feed-in tariff stayed constant at 20 years. Banks offering longer loan tenors is therefore an indication of higher confidence in the project. The debt service coverage ratio (DSCR) is a measure of project cash flows available to pay debt obligations, namely the principal repayment and interest rate payments. Lower DSCRs can thus be interpreted as an additional indication for lower project risk.

Solar PV

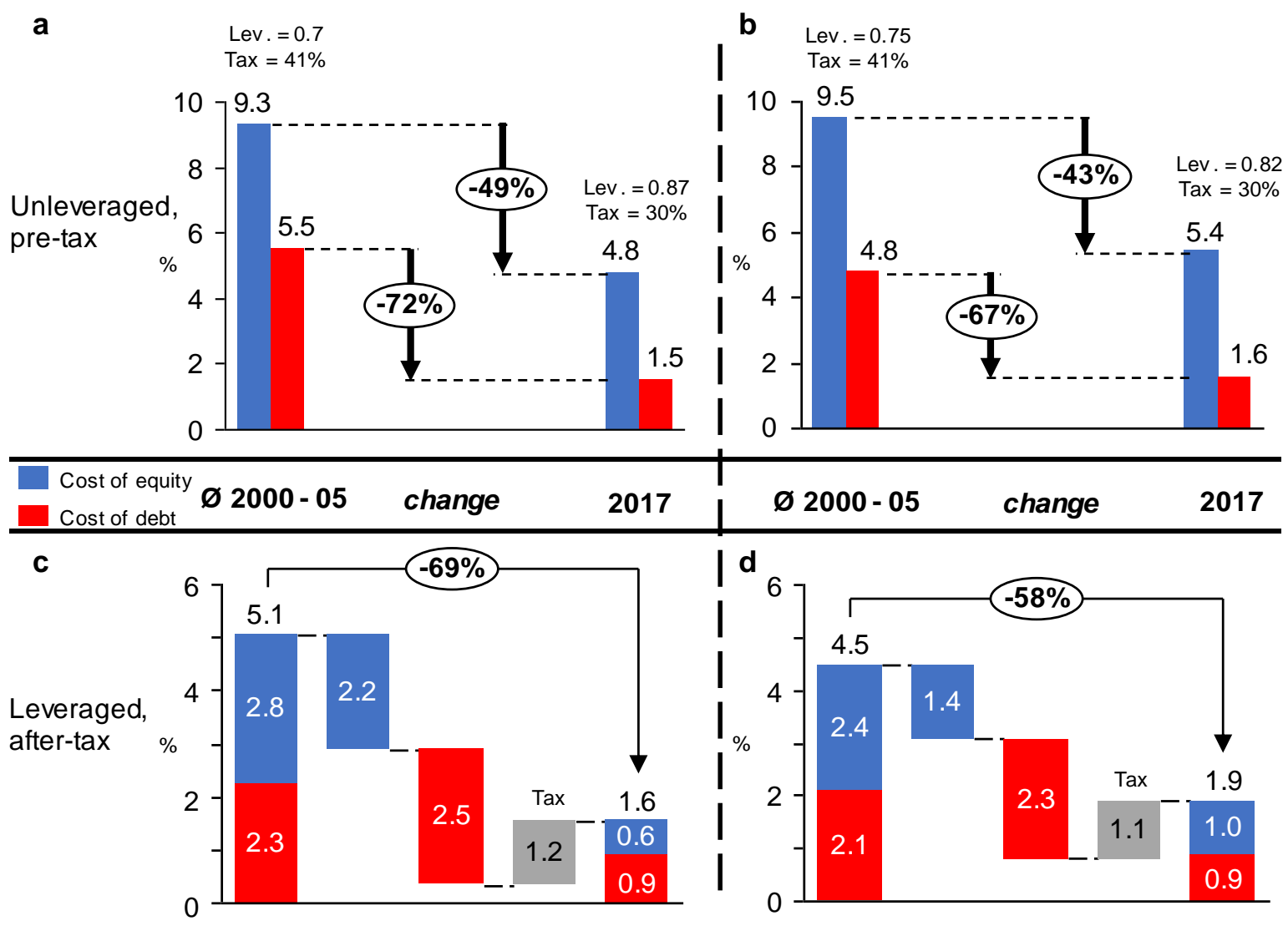

Figure 2: Components and dynamics of cost of capital. First row: changes in unleveraged (pre-tax) cost of debt and cost of equity (a) for solar PV and (b) wind onshore projects. Second row: changes in leveraged (after-tax) CoC (c) for solar PV and (d) wind onshore projects. The positive tax effect was due to a decrease in the corporate tax rate that led to a smaller cost reduction from tax deductible debt interest payments. 


\section{Drivers of change}

In the second step, we use qualitative interviews with investment professionals $(N=41$, see Supplementary Table 3) to inductively reveal and understand the underlying drivers of the observed changes in financing conditions ${ }^{27}$. Averaging more than ten years of renewable energy investment experience, the interviewees demonstrate an in-depth understanding of the market dynamics over time. From these interviews, we distil drivers of cost of capital reductions on three nested levels: the macroeconomic environment (economy), the renewable energy sector, and the renewable energy finance industry (see Methods). The latter two are related to experience gained through deployment and financing of RET. Figure 3 illustrates the main drivers on the three identified levels.

Level

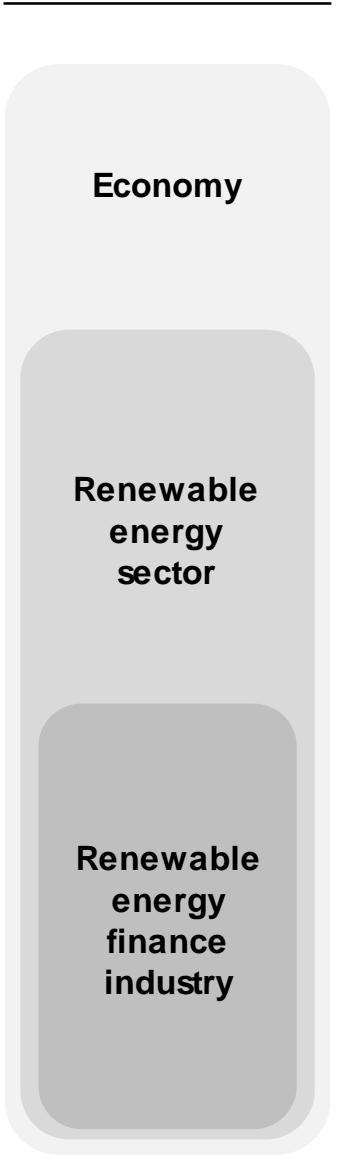

\section{Drivers of changes in financing conditions}

- Capital markets: Low-cost liquidity, few investment alternatives, low return expectations

- Banks: Low-cost refinancing, low bank fees, preference for project finance

- Availability of performance data: Accumulated operation experience of RET assets

- Technology reliability: Proven track record of technology, low default rates of projects

- Support policies: Regulatory environment, e.g. introduction of exposure to market risks

- Learning by doing: In-house RET knowledge, better risk assessment and due diligence processes

- Investment ecosystem: Standardised investment structures, frame contracts, partner networks

- Market entry of investors: New investor types (e.g., large banks, insurers, pension funds), increasing investor competition
Drivers related to general economic development
Drivers related to experience with deployment and financing of RET

Figure 3: Drivers of changes in financing conditions in a nested hierarchy (see Methods). The general economic environment led to more favourable financing conditions (for all sectors) over the period of our study. All drivers in the renewable energy sector and the renewable energy finance industry 
contributed to more favourable financing conditions (in the renewable energy sector) over the period of our study, with the exception of changes to support policies, which potentially introduce new uncertainties into RET deployment.

On the economy level, expansive monetary policies in the aftermath of the 2008-2009 financial crisis resulted in low refinancing costs for banks, which decreased the cost of capital of the economy ${ }^{28}$. The large supply of capital increased the pressure on bank fees and eventually lowered them, too. At the same time, extensive bank lending tended to lead to overconfident credit issuance, thereby increasing default rates ${ }^{29,30}$. The extensive lending made the evaluation of companies' credit eligibility more difficult and thereby increased the investment attractiveness of projects with predictable cash flows, such as RET assets in project finance structures.

On the renewable energy sector level, technology deployment had a favourable impact on financing conditions. As more renewable energy projects were undertaken, technologies became more mature, that is, more reliable. In parallel, the availability of data on technology performance made an assessment of this increasing reliability possible, while financial data showed low default rates. Together with a higher confidence in partners for construction and operation of RET assets, as these companies had increasingly established track records, these developments provided impetus for investment professionals to convince their boards to invest in renewable energy assets. According to our qualitative results, the deployment effect was more pronounced for solar PV than for wind onshore projects because of wind turbines' larger operational risk due to their design complexity ${ }^{31}$ and moving parts. Additionally, wind resource availability is more difficult to predict than solar irradiation. Partly as a result of these factors, the CoC decreased faster for solar PV projects than for wind onshore projects. Finally, stable and reliable RET support policies were a prerequisite for RET investment in Germany in the past ${ }^{23}$. However, gradually, some RET projects are being partly exposed to market prices $^{32,33}$, which is reflected by few shorter loan tenors and higher DSCRs (see Supplementary Figure 2). 
On the level of the renewable energy finance industry, investors benefited from growing RET markets and subsequent learning-by-doing (e.g., better risk assessment) ${ }^{34}$. Larger markets allowed banks to form in-house project finance teams specialised in RETs. The knowledge and data that these teams accumulated allowed for a more accurate technology assessment. Consequently, project risks declined. For example, as the market had accumulated experience on historical wind speeds, investors shifted from calculating project returns on wind resource estimations with $90 \%$ certainty $\left(90^{\text {th }}\right.$ percentile of the distribution, p90) to trusting the median (p50). While the observed increases in loan tenors and decreases in DSCRs (see Supplementary Figure 2) confirm lower project risk, we see two divergent trends in project leverage. On the one hand, investors advanced to higher leverages to increase returns on equity; on the other hand, some investors started to accept lower leverages to place their equity in a market environment with few renewable energy investment opportunities on offer.

Moreover, the investor ecosystem matured and competition increased. In a maturing investment market, institutional investors (e.g., insurers and pension funds) started to perceive renewable energy project finance as an attractive asset class. Institutional investors usually demand lower returns and larger project sizes than smaller early-stage investors ${ }^{35}$. The capital inflow from the new group of institutional investors hence created an incentive to build larger projects and increased competition for projects, which generally compressed debt margins further. While lower margins lead to lower LCOEs and are thus potentially conducive to RET deployment, some investors fear that the increasing capital inflow could create an asset bubble with financing conditions that would no longer reflect project risks. Lastly, the use of standardised deal structures facilitated the investment process and contributed to more efficient financing markets with lower margins.

\section{Financing experience rates}

The third step of our analysis focuses on the effects that are related to experience with deployment and financing of RETs (see Figure 3). The innovation literature has identified a roughly constant percentage unit cost decline - the experience or learning rate - with each 
doubling of cumulative production (Wright's law, see Methods) ${ }^{36}$. This experience effect is a well-known characteristic of RET investment $\operatorname{cost}^{14-16,37,38}$. Our results from the second step demonstrate that experience matters for the renewable energy finance industry. We hence propose a financial experience effect analogous to Wright's law ${ }^{39}$ and estimate a corresponding experience rate.

To identify the experience rate, we focus on debt, because this is where most cost reductions have occurred (compare Figure 2). We analyse three debt indicators that reflect investment safety margins, namely, the debt margin, DSCR and loan tenors. For riskier projects, investors demand higher debt margins as compensation, an increase in the DSCR to create a buffer in case of cash flow complications, and a decrease in the loan tenor to reduce the risk exposure to a shorter period. More experienced investors should be able to judge investment projects more accurately, thereby reducing the required safety margins and generating an empirically observable experience effect. Figure 4 shows the experience rates for the three variables. We find an experience rate of $11 \%$ on the debt margins of both technologies. We also detect experience rates of $13 \%$ for the DSCR of solar PV projects and of $17 \%$ for the DSCR of wind onshore projects (see Methods). Regarding the loan tenors, we find an experience rate of $3 \%$, that is, increasing loan tenors with increasing experience. However, this finding is insignificant for wind onshore projects. In sum, the third step of our analysis establishes the statistical significance of the experience effect in renewable energy financing, as found qualitatively in the second step. Increased RET deployment contributes to better financing conditions. 
Solar PV

a

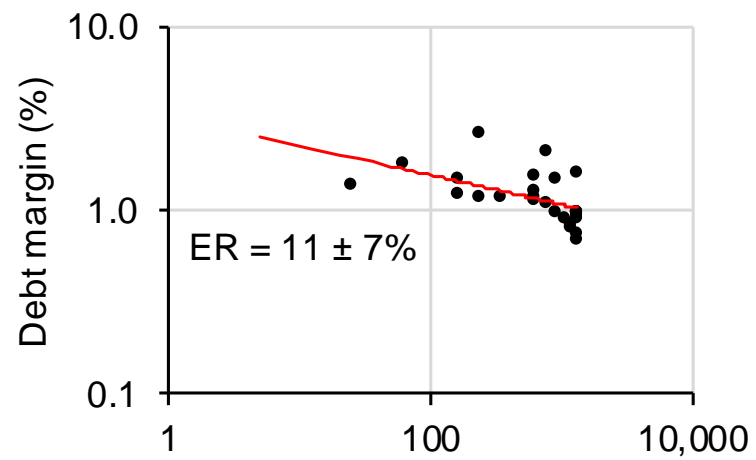

C

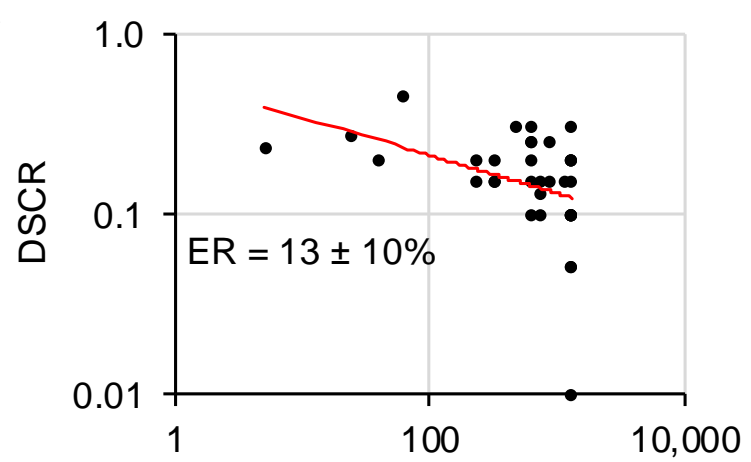

e

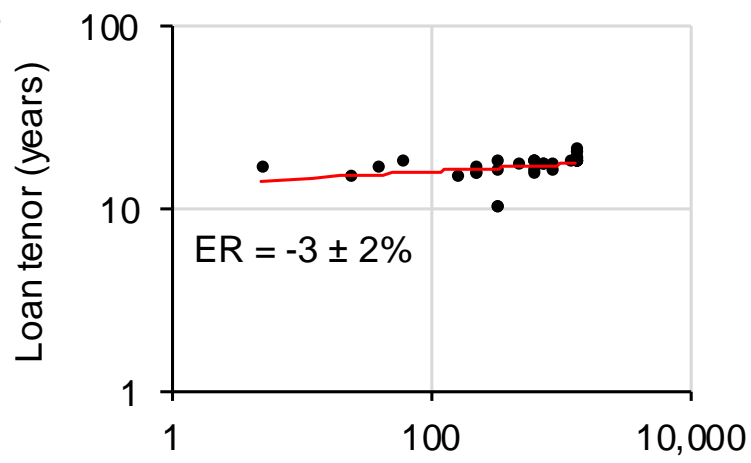

Cumulative world investment (USD bn) b

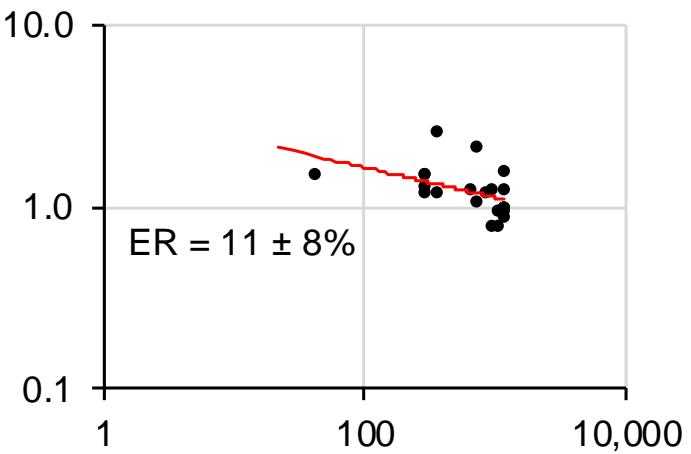

Wind onshore

d

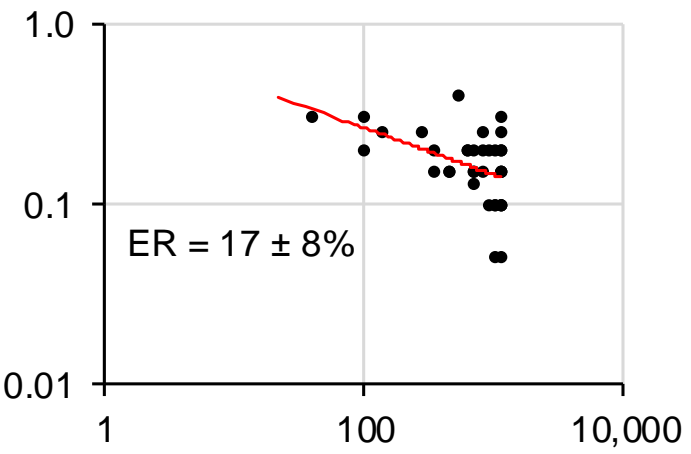

f

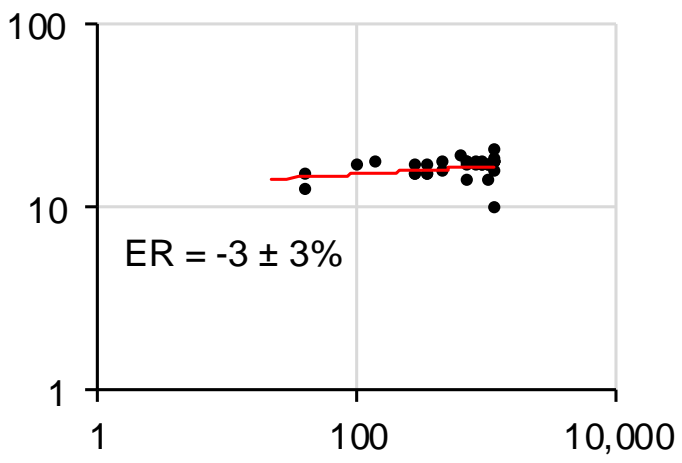

Cumulative world investment (USD bn)

Figure 4: Experience rates (ER) for risk metrics including the 95\% confidence interval. a, Debt margin ER for solar PV projects $(N=27)$ and $(\mathbf{b})$ for wind onshore projects $(N=22)$. c, Debt service coverage ratio (DSCR) ER for solar PV projects $(\mathrm{N}=35)$ and $(\mathbf{d})$ for wind onshore projects $(\mathrm{N}=36)$. e, Loan tenor ER for solar PV projects $(\mathrm{N}=36)$ and $(\mathbf{f})$ for wind onshore projects $(\mathrm{N}=34)$. All axes are in logs, and fits are linear. All linear fits are significant at the $5 \%$ level or below, except for the wind onshore loan tenors (f). Data from German projects between 2000 and 2017. Between 2000 and 2017, global cumulated solar PV investment doubled eight times, and wind onshore investment just short of six times. Results are robust to including investor fixed effects (e.g., controlling for different sizes of investors), 
choosing Europe as the relevant scope for experience (i.e. using European instead of global investment data) and using alternative data to measure investment (see Supplementary Tables 5-7).

In the following, we compare the experience effect with the exogenous effect (economy level) from changes in general interest rates. The cost of debt of a RET project can be decomposed into two elements covering the baseline country risk and project specific risk ${ }^{40}$. Figure 5 shows the yields of a 10-year German government bond (the best proxy for baseline country risk) and the estimated debt margins (the best proxy for project specific risk). While the bond yields are driven by monetary policy and exogenous to renewable energy deployment, the debt margins reflect dynamics related to experience with deployment and financing of RET.

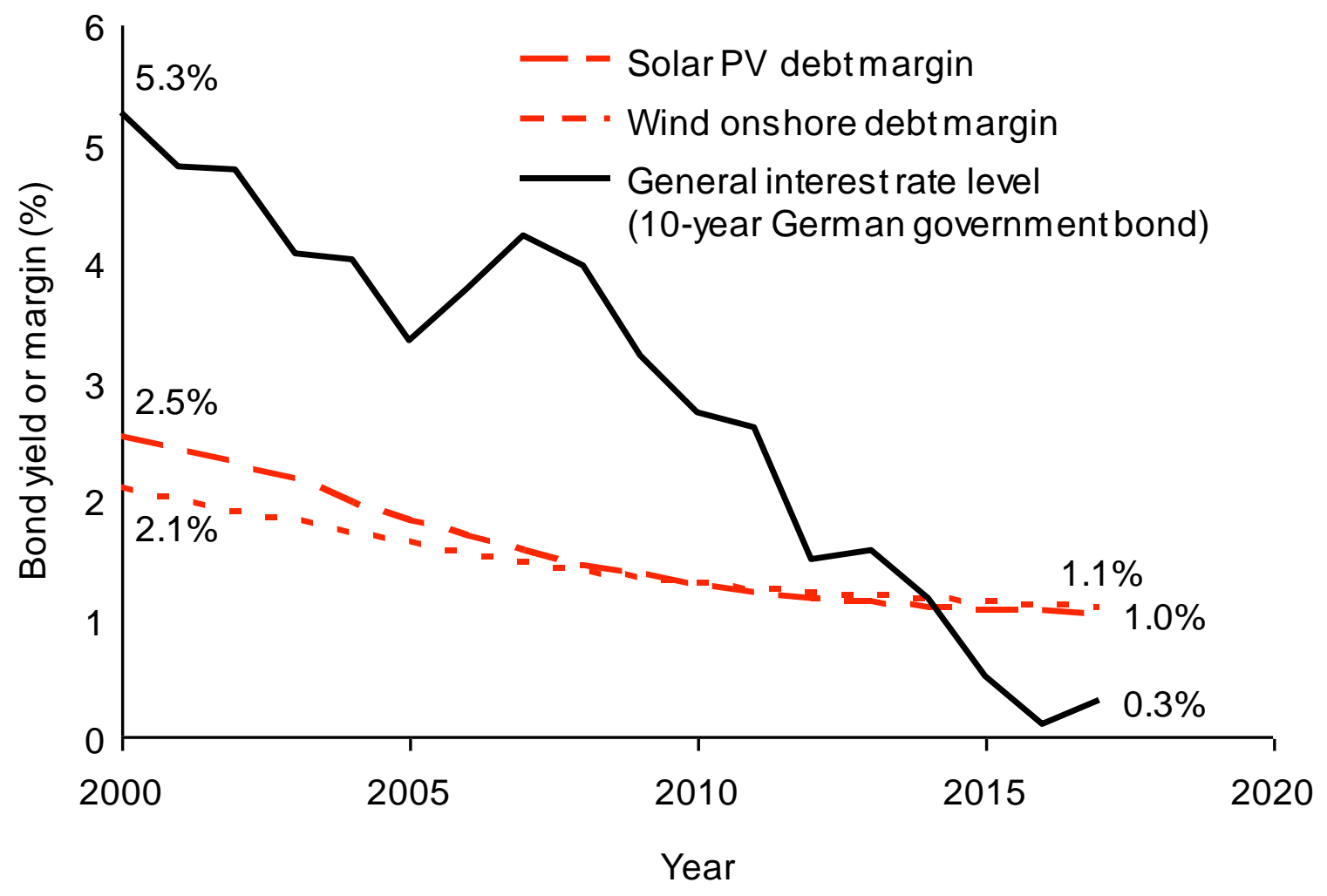

Figure 5: Changes in the baseline country risk versus project risk. Debt margins are predicted values using the estimated experience rate from Figure 4 and global investment data from 2000 to 2017 (see Methods). A data validity check regarding the decomposition of the cost of debt into debt margin and government bond yield is provided in Supplementary Figure 4.

Three observations can be made in Figure 5. First, the change in debt margins seems small compared with government bond yields but is economically substantial. While government 
bond yields decreased by $5 \%$ points, debt margins have declined by $1.5 \%$ points for solar PV projects and $1 \%$ point for wind onshore projects between 2000 and 2017 . For comparison, this decrease corresponds to a change in the corporate ratings of a financial service firm from $\mathrm{B}_{+}$ to AAA for solar PV or from BBB to AAA for wind onshore ${ }^{26}$. Second, Figure 5 reveals different dynamics between the two technologies. Due to larger increases in cumulative investment for solar PV, its debt margin decreased more than it was the case for wind onshore projects. As a relatively novel technology, solar PV projects were perceived riskier and thus charged with a higher debt margin in 2000. In 2017, investors no longer make a difference and charge almost identical margins. This catch-up of solar PV confirms the pattern shown in Figure 2 and the qualitative findings from the previous section. Third, debt margins are higher than the baseline country risk rate in 2017 , largely as a result of exceptionally low government bond yields due to the expansive monetary policy after the financial crisis. Considering the observed trend towards higher leverages and the concurrently increasing importance of the cost of debt, this finding points out that changes in the general interest rate level potentially have a large impact on the cost of capital for RETs.

\section{Impact on LCOE}

In the fourth and final step, we calculate the changes in LCOE resulting from the observed changes in the overall cost of capital between the early period of the RET finance industry (2000-2005) and 2017 (see Methods). 


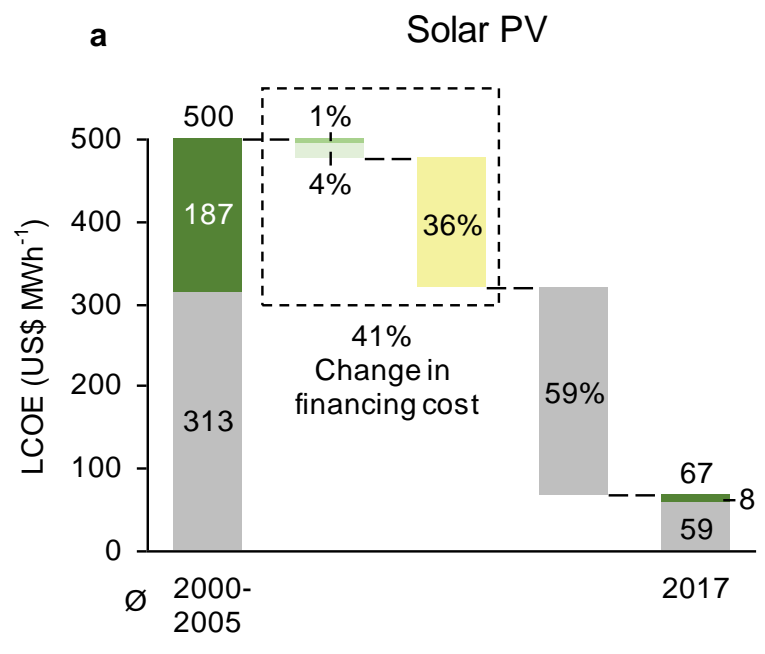

LCOE components

Financing expenditures

Capital and operating expenditures b Wind onshore

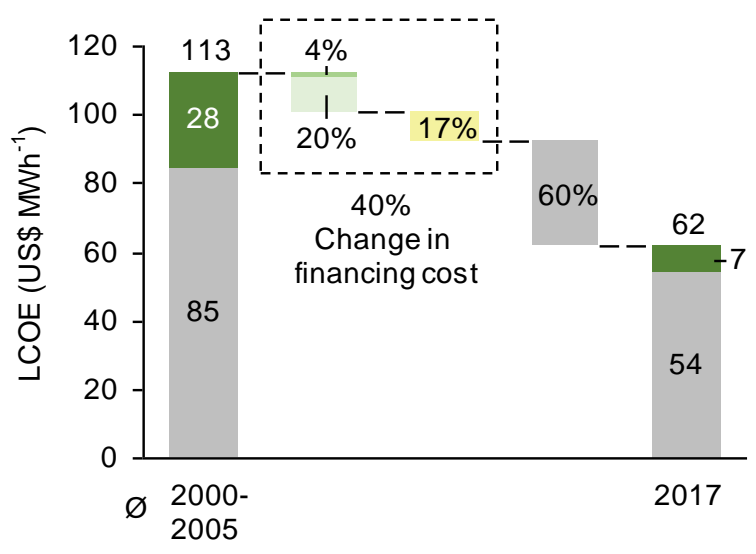

Change in financing cost from...

... experience effect

... general interest rate effect

.. lower capital expenditures

Figure 6: Historical impact of changes in financing costs on levelised cost of electricity (LCOE) for (a) solar PV (b) wind onshore. Percentages indicate the contributions of the respective parts to the change in LCOE. We parametrise the LCOE model using data for Germany (see Supplementary Table 4). Sensitivities are provided in Supplementary Figure 5. Numbers do not always add up due to rounding.

Figure 6 shows that the solar PV LCOE in Germany dropped by US $\$ 433 \mathrm{MWh}^{-1}$, with US $\$ 179$, or $41 \%$, attributed to lower financing costs. In the case of wind onshore, the LCOE dropped by US $\$ 51 \mathrm{MWh}^{-1}$, with US\$20, or $40 \%$, attributed to lower financing costs. For comparison, these reductions bring both technologies into the generation cost ranges for fossil fuel-fired power plants, estimated to be between US $\$ 50$ and US $\$ 170$ for G20 countries in $2017^{41}$.

We distinguish three effects contributing to the change in financing costs. First, the initial investment to be financed (CAPEX) decreased, which lowers the financing cost. Second, the general interest rate decreased. Third, an experience effect led to the compression of financing margins. The three effects differ in importance between the two studied technologies. The large reduction in Solar PV CAPEX during the period of our study (see Supplementary Table 4) led to lower financing costs, which contributed to roughly one third (36\%) of LCOE reductions. Conversely, onshore wind CAPEX stayed relatively constant (see Supplementary 
Table 4), increasing the relative importance of the general interest rate effect, which contributed to one fifth (20\%) of LCOE reductions. Thus, the channels through which financing costs contribute to lowering LCOEs vary according to the relative reductions in CAPEX. As solar PV and wind onshore are becoming mature technologies and future CAPEX reductions become less likely, the relative importance of the general interest rate and experience effects will increase.

\section{Discussion}

This paper compiles a project level dataset for financing conditions and makes three contributions. First, it identifies the drivers of the changes in financing conditions. Second, it estimates an experience effect for financing conditions and compares it with the changes in the general interest rate. Third, it demonstrates the effect of the changes in financing conditions on the LCOE.

For researchers, our results suggest that the dynamics of financing conditions should receive more attention in models that include investments in low-carbon technologies. In failing to account for these dynamics, researchers could overestimate the technology learning effect by attributing the full LCOE change to reductions in capital and operating expenditures. Accounting for different channels of LCOE reductions via financing costs may be particularly important - especially as the increasing use of auctions makes data on generation costs readily available, increasing the use of LCOE learning curves ${ }^{41}$. To include sensitivity analyses regarding the dynamics of financing conditions in models, further research should help improve the understanding of the processes that affect renewable energy financing conditions. While we have separated three effects contributing to financing costs' LCOE effect, their dynamics are yet to be fully understood, opening up avenues for future research. For example, it is not evident whether deployment and the associated reductions in investment costs would have been as large as observed without reductions in the $\mathrm{CoC}$. The accumulation of experience in the finance industry, the excess availability of capital and the reductions in investment costs all depend on each other and together constitute the impact of financing costs on the LCOE. 
Future research also should investigate to what extent this paper's conclusions are applicable to other regions and other technologies.

For policymakers, our findings stress the importance of policies that are conducive to favourable financing conditions for low-carbon technologies. First, our results suggest an important co-benefit of deployment policies: the acceleration of technological change by allowing the finance industry to experiment and learn. RET investments are long-term, and the finance industry typically struggles to assess long-term risks of new technologies without track record $^{34,42}$. For instance, green state investment banks can be an instrument to accelerate learning in the finance industry, helping investors assess projects and build confidence in new technologies ${ }^{43}$. Second, our results indicate that a large RET financing market and a high degree of competition between investors were crucial in creating more favourable financing conditions for RETs. Therefore, policies should try to crowd-in a broad spectrum of investors. Third, our findings point out that policymakers should be vigilant in responding to changes in monetary policies that have an impact on RET costs. As RET generation costs approach grid parity, policymakers in some countries consider phasing out fixed remuneration schemes for RETs. While some have argued that achieving high RET shares requires de-risking policies in any case ${ }^{44}$, our results stress the particular importance of policy intervention (e.g., RET support or carbon pricing) given the likelihood of an imminent increase in interest rates. Ending policies might be premature and put climate change targets at risk. Policymakers also could evaluate new approaches, such as green monetary policies, to ensure attractive financing conditions for low-carbon technologies in the future ${ }^{45}$. 


\section{Methods}

\section{Case selection}

The case selection includes three dimensions: technology, country and project type. First, we focus on solar PV and wind onshore technologies, the most deployed non-hydro RETs. In 2016, solar PV and wind onshore technologies accounted for a global capacity of 291 GW and $452 \mathrm{GW}$, respectively (e.g., compared with $14 \mathrm{GW}$ for wind offshore generation) ${ }^{46}$. Second, we focus on Germany, one of the earliest markets to adopt these technologies. Germany added the most solar PV capacity in 13 of the 17 years analysed, and the most wind onshore capacity in eight of the 17 years analysed ${ }^{46}$. Our sample period begins in 2000, when Germany enacted its landmark legislation on renewable energy sources (EEG), with a feed-in tariff that triggered large-scale renewable energy investments ${ }^{23}$. The feed-in tariff was never changed retroactively. The German electricity market has been liberalised since $1998^{23}$, and the vast majority of investment in RET was private ${ }^{47}$. Third, we restrict the analysis to project finance structures, exploiting the fact that $96 \%$ of large solar PV projects and $88 \%$ of large wind onshore projects in Germany between 2000 and 2015 were undertaken using project finance ${ }^{24}$.

\section{Key terms of project finance}

In project finance, each project is a separate legal entity, set up for the project's lifetime, often called a special purpose vehicle (SPV). The project sponsors hold equity in the SPV, and banks typically provide loans (i.e., debt) to the SPV. In this paper, we call both project sponsors and banks investors. The expected returns to project sponsors are called cost of equity, and the interest to be paid on the loans is called cost of debt. The relative shares of debt and equity in a project define the leverage or capital structure of the SPV. Loan providers usually have no recourse beyond the project, which means the project's risk profile translates directly to the cost of debt. Consequently, the cash flows generated by the SPV must cover operating costs and the debt service (i.e., capital repayment and interest) ${ }^{25}$. Any remaining cash flows go to the project sponsors and constitute their return on the investment. Therefore, equity investors 
also are concerned about a project's ability to service outstanding debt. The common metric to assess debt service is the debt service coverage ratio (DSCR), which serves as a direct measure of project risk (see Supplementary Table 1). Moreover, the SPV's capital structure usually also is an indication of project risk because more debt increases the debt service (just as a higher cost of debt does). As per convention, we analyse the financing conditions of SPVs at the beginning of projects, i.e., the point when investors make their investment decisions. Contrary to corporate finance, project finance directly ties the cost of capital to project risk ${ }^{24,25}$ - providing a unique setting in which to study the dynamics of renewable energy financing conditions. Because project finance conditions are not quoted publicly, it is necessary to elicit data from renewable energy investment professionals.

\section{Data collection}

We contacted leading investors directly to assemble two sets of data: quantitative data on the financing conditions of reference projects, and qualitative data on the drivers of changes in financing conditions. The former is used for steps one, three and four of the paper, and the latter is used for step two. All investor interviews were conducted between September 2017 and January 2018, following the Chatham House Rule, which states that 'participants are free to use the information received, but neither the identity nor the affiliation of the speaker(s) [...] may be revealed'48. The interviews were conducted in person or over the phone by one to three researchers who took individual notes. All interviews were recorded and transcribed verbatim.

We use theoretical sampling to include the most revelatory interviewees and balance our sample to represent various perspectives from the finance industry ${ }^{27,49}$. The sampling took place in three stages. First, we searched for publicly available addresses of senior investment professionals working at large debt and equity investment firms, using the Bloomberg New Energy Finance (BNEF) database ${ }^{50}$. Second, we used the contact network of a private renewable energy finance industry partner in the INNOPATHS research consortium, Allianz Climate Solutions (ACS), to reach out to relevant market actors. Third, we employed snowball 
sampling by asking key contacts from our network to refer us to relevant actors and teams, then continued to ask for references upon each contact with an investment professional. The resulting sample is well-balanced among different kinds of financial actors and includes 17 debt providers (13 commercial banks and four investment banks), 16 equity providers, seven public actors (four public utilities and three public investment banks), and one former researcher (see Supplementary Table 3 for the full interviewee sample). The sampled financial actors were lead arrangers in $81 \%$ of solar PV capacity additions and $85 \%$ of the solar PV investment sum, and in $49 \%$ of onshore wind capacity additions and $80 \%$ of the onshore wind investment sum, between 2000 and 2017 (see Supplementary Figure 1). Thus, our sample covers the relevant actors in a balanced manner and is relevant in size to elicit financing conditions that are representative of the German investment market. Because the renewable energy finance industry is international, the investment professionals in our sample are based in different countries, albeit all European. 20 investment professionals are based in Germany, 10 in Switzerland, four in the UK, three in the Netherlands and one each in France, Italy, Luxemburg and Norway.

\section{Quantitative data}

To ensure comparable data on project financing conditions, we defined a reference project with an investment sum of $€ 20$ million, using standard technology from established manufacturers (poly-crystalline modules without a tracker for solar PV projects and 1.5-2 MW turbines on a standard foundation for wind onshore projects). While the relatively small standard deviation of the data (see Supplementary Table 2) indicates a good comparability of projects across investors, we control for investor differences (e.g., investor size) by including investor fixed effects in the estimations of experience rates (see below).

We asked the investment professionals to provide information on the all-in cost of capital, cost of debt, cost of equity, debt margin, DSCR, leverage (i.e., project capital structure) and loan duration (tenor) for any such reference project that they had financed (which is the case for 37 interviewees) or had advised on (which is the case for four interviewees; see Supplementary 
Table 3) between 2000 and 2017 (see Figure 1 and Supplementary Figure 2). For cost of capital components (cost of debt, cost of equity and leverage), the interviewees were free to indicate ranges instead of absolute values, in which case, we take the average by project. Wherever possible, the debt providers indicate not only the all-in cost of debt, but also the debt margins. For projects with available information on debt margins, we calculate the all-in cost of debt as the sum of the baseline rate (10-year government bond $\left.{ }^{51}\right)$ and the debt margin. This approach yields all-in cost of debt data comparable to where debt providers revealed all-in costs of debt (see Supplementary Figure 4). Additionally, we screen publicly available onshore wind park investment prospectuses - mainly from civic-owned assets (German Bürgerwindparks) - between 2000 and 2017 for the data on the cost of debt. We do not consider this source for the cost of equity data because investment prospectuses often offer overly optimistic equity returns ex-ante. On the other hand, the cost of debt figures reflect the rates offered by banks. The resulting dataset consists of 48 solar PV and 85 wind onshore projects. The number of observations, means, standard deviations, and minimums and maximums for all variables are described in Supplementary Table 2.

To estimate experience rates, we use investment data from the United Nations Environment Programme $(\mathrm{UNEP})^{52}$, which is available from 2004 onward. For the years prior to 2004, we take global investment costs per MW for solar PV and wind onshore projects ${ }^{50}$ and multiply these figures with global capacity from the International Renewable Energy Agency (IRENA) ${ }^{46}$. For 2000 and 2001, we used the solar PV investment costs from 2002 because ref. 50 provides no data. For 2017, we extrapolate the changes from the previous year.

\section{Qualitative data}

To develop the drivers of changes in financing conditions, we apply an interview case study design with two stages of data collection ${ }^{53}$. First, open exploratory interviews $(\mathrm{N}=8)$ were conducted to gain early insights on the dynamics and drivers of changes in financing conditions and to define the structure for the second phase of the interviews. Second, we conducted 33 semi-structured interviews with employees from debt and equity investment firms who had 
significant experience in the renewable energy finance industry (23 of these interviewees are the same individuals who provided the quantitative data mentioned above). Note that we contacted three investment professionals from the exploratory interviews again for the semistructured interviews and the collection of project financing conditions data.

If more than one researcher conducted an interview $(\mathrm{N}=15)$, one of them summarised it using the recording, transcript and notes. If only one researcher conducted the interview $(\mathrm{N}=26)$, the resulting summary was cross-checked by another researcher. This procedure ensures accurate and consistent recording, expands the scope of insights and enhances confidence in the findings ${ }^{53}$. Following Eisenhardt's approach ${ }^{53}$, we continued holding interviews until no additional insights were observed.

\section{Changes in financing conditions}

In the first step of the paper, we calculate the project cost of capital (CoC) before and after taxes because the German corporate tax rate was cut four times, from an initial $52 \%$ in 2000 to $30 \%$ in 2008 , and remained at that level until $2017^{54}$ (see Supplementary Figure 3). Equations (1) and (2) define the pre- and after-tax CoC.

$$
\begin{gathered}
\text { Pre-tax CoC }=K_{E} \frac{E}{V}+K_{D} \frac{D}{V} \\
\text { After-tax CoC }=K_{E} \frac{E}{V}+K_{D} \frac{D}{V}(1-T)
\end{gathered}
$$

In these equations, $E$ and $D$ denote equity and debt investment, respectively; $V$ signifies the total investment sum; $K_{E}$ and $K_{D}$ refer to cost of equity and cost of debt, respectively; and $T$ represents the corporate tax rate. The leverage $L$ is equal to $D / V$. To analyse the changes over time, we use the average during the $2000-2005$ period as the starting point due to limited data availability in the early years. Because costs of capital decreased already between 2000 and 2005, this approach yields a conservative estimate for the changes over time. 
Taking the derivatives of Equation (2) yields Equations (3-6), below. Equations (3) and (4) show that the changes in the cost of equity and debt affect the cost of capital, depending on leverage and corporate tax rate. Equation (5) shows that the effect of increasing leverage depends on the difference between $\mathrm{K}_{\mathrm{D}}$ and $\mathrm{K}_{\mathrm{E}}$. More precisely, if $(1-T) K_{D}<K_{E}$ holds, the cost of capital decreases with increasing project leverage. Typically, this condition holds in reality (see characteristics of project finance above). Equation (6) illustrates that a change in the tax rate affects costs of capital in the opposite direction, i.e., a decrease in the tax rate increases costs of capital.

$$
\begin{gathered}
\frac{\partial C o C}{\partial K_{E}}=(1-L) \\
\frac{\partial C o C}{\partial K_{D}}=(1-T) L \\
\frac{\partial C o C}{\partial L}=(1-T) K_{D}-K_{E} \\
\frac{\partial C o C}{\partial T}=-L K_{D}
\end{gathered}
$$

Figures $2 \mathrm{c}$ and $2 \mathrm{~d}$ represent this fact with a grey upward bar for tax changes, indicating the higher cost of capital due to the lower corporate tax rate.

\section{Drivers of change}

In the second step, we use qualitative data to establish the drivers behind the changes in financing conditions. The interviews were semi-structured in the sense that the interviewees were free to name and explain the main drivers that led to the changes in financing conditions, but the conversations followed a pre-determined set of topics. At the end of each interview, we asked the interviewee whether crucial points were missing. This feedback was included iteratively in the first few interviews. Key statements were summarised by two researchers after each interview. Once the interview summaries were completed (see data collection above), we loosely followed the 'grounded theory' approach ${ }^{55}$ by comparing incident (i.e., statement) 
to incident to iteratively create common patterns and drivers. We constantly compared new incidents with emerging drivers (recursive cycling among different investor interviewees) ${ }^{27}$. Two researchers conducted this 'constant comparison', verifying drivers and ensuring their accuracy ${ }^{56}$. As a result, we identified eight drivers, which we categorised in a nested hierarchy of three levels: economy, renewable energy sector and renewable energy finance industry.

\section{Financing experience rates}

In the third step, we apply a one-factor experience curve, following Wright's law ${ }^{39}$, and adapt it to financial indicators. Applying a one-factor experience curve may lead to estimates that are biased upwards due to an omitted variable bias ${ }^{57}$. The most commonly cited omitted factor is research and development (R\&D) spending ${ }^{38,58}$. However, service industries, such as the finance industry, typically do not use R\&D departments, or even the term R\&D. Instead, innovation activities are organized in project-based teams ${ }^{59}$. Perhaps as a consequence, some empirical evidence even points to a negative effect of R\&D spending on service innovation ${ }^{60}$. Finally, the evidence of our interviews points to factors such as track records, improved processes or market competition as drivers of the experience effect. Quantifying these factors individually is impossible, which is why we choose to use a one-factor experience curve and discuss the components qualitatively in step two. For each of the financial indicators (i.e., debt margin, DSCR and loan tenor), we define experience curves as follows:

$$
\begin{gathered}
\operatorname{DebtMargin}\left(I_{t}\right)=\operatorname{DebtMargin}\left(I_{0}\right)\left(\frac{I_{t}}{I_{0}}\right)^{-b_{1}} \\
\operatorname{DSCR}\left(I_{t}\right)=\operatorname{DSCR}\left(I_{0}\right)\left(\frac{I_{t}}{I_{0}}\right)^{-b_{2}} \\
\operatorname{Tenor}\left(I_{t}\right)=\operatorname{Tenor}\left(I_{0}\right)\left(\frac{I_{t}}{I_{0}}\right)^{-b_{3}}
\end{gathered}
$$

In Equation (7), DebtMargin denotes the debt margin in percentage points. In Equation (8), DSCR signifies the transformed debt service coverage ratio. We transform the elicited DSCR 
values by subtracting 1 because the DSCR has a natural lower bound of 1 . As we are taking the log in the next stage, we transform one value in our sample from 0 to 0.01 . In Equation (9), Tenor represents loan tenor duration in years. In all three equations, I refers to the cumulative world investment volume in billions of US dollars, and $b_{1-3}$ signifies the experience parameter for each variable. In each Equation (7-9), $I_{0}$ denotes the first investment, and $I_{t}$ represents cumulative investment at time $t$.

We define an individual experience rate, $E R=1-2^{-b}$, for each variable of interest and quantify it by estimating Equations (7-9) separately for both technologies $i$, using an ordinary least squares (OLS) regression according to Equation (10):

$$
\ln \left(D V_{i t}\right)=\beta_{0 i}+\beta_{1 i} \ln \left(I_{i t}\right)+\varepsilon_{i},
$$

In which $t$ denotes the year, $D V$ denotes the dependent variable (see Equations 7-9), and, again, I signifies cumulative world investment in billions of US dollars.

As mentioned previously, a potential caveat concerning the data is the heterogeneity of investors. Thus, we apply investor fixed effects in a robustness check, which does not change the results (see Supplementary Tables 5 and 6). The choice of the independent variable in the specification of the experience rate also is subject to some debate in extant literature. Depending on the technology and application, the relevant geographical scope to accumulate experience changes ${ }^{61}$, which affects the empirical identification of experience rates ${ }^{58}$. While the evidence indicates global experience effects for RETs because innovation benefits cannot be kept locally ${ }^{34}$, this argument should hold even more for the finance industry - especially as large investors usually are active internationally. Our choice of cumulative global investment is driven by exploratory investor interviews, which point out that the financing of large project finance deals is international and increasingly global, so global investment figures appear to be the most relevant. However, because our investor sample is Europe-based (see Supplementary Table 3), we test for a European specification of the experience effect by using cumulative European investment. We do so by using capacity data for Europe from IRENA ${ }^{46}$ and investment cost data for Germany from BNEF ${ }^{50}$ (three-year moving average). The results 
remain very similar for solar $\mathrm{PV}$, but estimates for the wind onshore experience rate become larger (see columns 3 and 4 in Supplementary Tables 5 and 6). Finally, we conduct a robustness check with alternative investment data sources, using global data on investment cost per $\mathrm{MW}^{50}$ (three-year moving average) and IRENA data on global capacity additions ${ }^{46}$. The results do not change (see columns 5 and 6 in Supplementary Tables 5 and 6 ). We always use robust standard errors to allow for heteroscedastic residuals (e.g., decreasing variance of the error term with decreasing debt margins because the market is becoming more competitive). Along most specifications, the results remain very similar. In cases when they change, we report a conservative experience effect by using global cumulative investment (i.e., typically equal or close to the lowest value across specifications). We report the range of the estimated experience rates across all specifications in Supplementary Table 7.

\section{Impact on $L C O E$}

In the fourth step, we calibrate an LCOE model according to Equation (11) to quantify the effect of the observed changes in financing costs on lifetime RET generation costs. We calculate the LCOE for both technologies $i$ (solar PV and wind onshore) and the two points in time, $t$ ( $t=1$ in 2000-2005; $t=2$ in 2017), as displayed in Figure 6.

$$
L C O E_{i t}=\frac{C_{i t}+\sum_{\tau=1}^{\tau=20} \frac{C_{i t \tau}}{\left(1+C o C_{i t}\right)^{\tau}}}{\sum_{\tau=1}^{\tau=20} \frac{F L H_{i t \tau}}{\left(1+C o C_{i t}\right)^{\tau}}}
$$

$C_{i t}$ denotes the initial investment cost per MW at $\tau=0, C_{i t \tau}$ represents the operation and maintenance costs per MW per year from $\tau=1$ to $\tau=20$ (constant) and $F L H_{i t \tau}$ signifies the full load hours of the asset per year from $\tau=1$ to $\tau=20$ (constant). Our discount rate CoC $_{i t}$ is the technology- and time-specific cost of capital.

On the OPEX, we assume $2 \%$ annual inflation. We parametrise the LCOE model by using real data for full load hours ${ }^{62,63}$, investment cost $\left(\mathrm{US} \$ \mathrm{MW}^{-1}\right)^{50}$ and operation and maintenance cost (US\$ MW-1 year $\left.^{-1}\right)^{64,63}$ in Germany, and the cost of capital from our project database. 
For both points in time $t$, we estimate a baseline with $0 \%$ cost of capital. We separate this baseline into CAPEX, represented by the first term of Equation (12) and an OPEX component represented by the second term.

$$
L C O E_{i t, C o C=0}=\frac{C_{i t}}{\sum_{\tau=1}^{\tau=20} F L H_{i t \tau}}+\frac{\sum_{\tau=1}^{\tau=20} C_{i t \tau}}{\sum_{\tau=1}^{\tau=20} F L H_{i t \tau}}
$$

We then estimate the same model with the observed cost of capital from our data $r_{i t}$ and define the change to the baseline as the financing expenditures $\delta_{i t}$ of the LCOE (see Equation 13). Note that $r_{i t}$ depends on the project leverage and tax rate according to Equation 2.

$$
\delta_{i t}=L C O E_{i t, C O C_{i}=r_{i}}-L C O E_{i t, C o C=0}
$$

As a result, we obtain three LCOE components (CAPEX, OPEX, and financing expenditures) for both technologies at both points in time, which allows us to display the changes in each component over time. We define the change in the financing expenditures, $\delta_{i t}$ as $\Delta_{i}$ following Equation (14). Note that in Figure $6, \Delta_{i}$ is denoted 'change in financing cost'.

$$
\Delta_{i}=\delta_{i, t=1}-\delta_{i, t=2}
$$

In the final step, we disentangle three effects that contribute to the change in financing cost, namely experience effect $\Delta_{i}^{E X P}$, general interest rate effect $\Delta_{i}^{I N T}$ and the effect resulting from lower CAPEX to be financed $\Delta_{i}^{\text {CAPEX }}$. The sum of the three effects equals the total change in financing cost by definition as shown in Equation (15).

$$
\Delta_{i}=\Delta_{i}^{E X P}+\Delta_{i}^{I N T}+\Delta_{i}^{C A P E X}
$$

We start with the last term and define the effect resulting from lower CAPEX as the hypothetical LCOE change with constant CoC (part 1 of Equation 16) minus the 'pure' CAPEX and OPEX changes (identical to the LCOE at $\mathrm{COC}=0$ ). In doing so, we define a counterfactual scenario of 
identical technological change (i.e., lower capital expenditure), absent changes in financing conditions. Given the mutually reinforcing mechanism of financing conditions and technological change (e.g., it is not clear that the capital expenditure would have decreased, absent improvements in financing conditions), this approach might overestimate the part of change attributed to $\Delta_{i}^{\text {CAPEX }}$. As a consequence, Equation (15) provides conservative estimates of the other two effects:

$$
\Delta_{i}^{C A P E X}=L C O E_{i, t=1, C o C[t=1]}-L C O E_{i, t=2, C o C[t=1]}-\left(L C O E_{i, t=1, C o C=0}-L C O E_{i, t=2, C o C=0}\right)
$$

To separate the remaining part of the change in financing cost into experience effect and general interest rate effect, we use the share of the debt margin of the total change in cost of debt $(\varphi)$. In Equation (17), $d$ denotes the difference between the value in 2017 and the value in 2000-05, and GenlntRate represents the general interest rate. Note that this is computing the share of the changes displayed in Figure 5.

$$
\varphi_{i}^{\text {DEBT }}=\frac{d\left(\text { DebtMargin }_{i}\right)}{d\left(\text { DebtMargin }_{i}+\text { GenIntRate }\right)}
$$

We assume that a similar relation holds for the equity side and stipulate $\varphi_{i}^{D E B T}=\varphi_{i}^{E Q U I T Y}=\varphi_{i}$. Combining Equations (14, 16 and 17), we now can identify the experience effect $\Delta_{i}^{E X P}$ and the general interest rate effect $\Delta_{i}^{I N T}$, which are shown in Equations (18) and (19).

$$
\begin{gathered}
\Delta_{i}^{E X P}=\varphi_{i}\left(\Delta_{i}-\Delta_{i}^{C A P E X}\right) \\
\Delta_{i}^{I N T}=\left(1-\varphi_{i}\right)\left(\Delta_{i}-\Delta_{i}^{C A P E X}\right)
\end{gathered}
$$




\section{Acknowledgements}

The authors thank members of ETH Zurich's Energy Politics Group, Matthias Jäger, Michael Pahle, Friedemann Polzin, Lisa Reile and Oliver Tietjen from the INNOPATHS project and participants of the 2017 oikos Finance Academy at the University of Zurich for helpful comments on earlier drafts of the paper. This work was supported by the Swiss State Secretariat for Education, Research and Innovation (SERI) under contract number 16.0222. The opinions expressed and arguments employed herein do not necessarily reflect the official views of the Swiss Government. This work was conducted as part of the European Union's Horizon 2020 research and innovation programme project INNOPATHS under grant agreement No. 730403.

\section{Author contributions}

All authors contributed to the research design, the data collection, the analysis and the writing. 


\section{References}

1. IPCC. in Climate Change 2014: Mitigation of Climate Change. Contribution of Work-ing Group III to the Fifth Assessment Report of the Intergovernmental Panel on Climate Change (eds. Edenhofer, O. et al.) (Cambridge University Press, 2014).

2. OECD. Climate Finance in 2013-14 and the USD 100 billion goal. a report by the Organisation for Economic Cooperation and Development (OECD) in collaboration with Climate Policy Initiative (CPI) (OECD Publishing, 2015).

3. Polzin, F. Mobilizing private finance for low-carbon innovation - A systematic review of barriers and solutions. Renew. Sustain. Energy Rev. 77, 525-535 (2017).

4. OECD/IEA \& IRENA. Perspectives for the energy transition - investment needs for a low-carbon energy system. (2017).

5. Williams, J. H. et al. 2050 : The Pivotal Role of Electricity. Science 335, 53-60 (2012).

6. Chu, S. \& Majumdar, A. Opportunities and challenges for a sustainable energy future. Nature 488, 294-303 (2012).

7. Schmidt, T. S. Low-carbon investment risks and de-risking. Nat. Clim. Chang. 4, 237-239 (2014).

8. Hirth, L. \& Steckel, J. C. The role of capital costs in decarbonizing the electricity sector. Environ. Res. Lett. 11, 114010 (2016).

9. NREL (National Renewable Energy Laboratory). 2017 Annual Technology Baseline. (2017).

10. Ondraczek, J., Komendantova, N. \& Patt, A. WACC the dog: The effect of financing costs on the levelized cost of solar PV power. Renew. Energy 75, 888-898 (2015).

11. Iyer, G. C. et al. Improved representation of investment decisions in assessments of $\mathrm{CO} 2$ mitigation. Nat. Clim. Chang. 5, 436-440 (2015).

12. Creutzig, F. et al. The underestimated potential of solar energy to mitigate climate change. Nature Energy (2017).

13. Shrimali, G., Nelson, D., Goel, S., Konda, C. \& Kumar, R. Renewable deployment in India: Financing costs and implications for policy. Energy Policy 62, 28-43 (2013).

14. Trancik, J., Brown, P., Jean, J., Kavlak, G. \& Klemun, M. Technology improvement and emissions reductions as mutually reinforcing efforts. Inst. Data, Sytems, Soc. Massachusetts Inst. Technol. (2015).

15. Nemet, G. F. Beyond the learning curve: factors influencing cost reductions in photovoltaics. Energy Policy 34, 32183232 (2006).

16. Bolinger, M. \& Wiser, R. Understanding wind turbine price trends in the U.S. over the past decade. Energy Policy 42, 628-641 (2012).

17. Hall, S., Foxon, T. J. \& Bolton, R. Investing in low-carbon transitions: energy finance as an adaptive market. Clim. Policy 17, 280-298 (2017).

18. Brunnschweiler, C. N. Finance for renewable energy: An empirical analysis of developing and transition economies. Environ. Dev. Econ. 15, 241-274 (2010).

19. Best, R. Switching towards coal or renewable energy? The effects of financial capital on energy transitions. Energy Econ. 63, 75-83 (2017).

20. Best, R. \& Burke, P. J. Adoption of solar and wind energy: The roles of carbon pricing and aggregate policy support. Energy Policy 118, 404-417 (2018).

21. Ecofys. The impact of risks in renewable energy investments and the role of smart policies. EU DiaCore Final Rep. 
(2016).

22. Ecofys. Mapping the cost of capital for wind and solar energy in South Eastern European Member States. (2017).

23. Jacobsson, S. \& Lauber, V. The politics and policy of energy system transformation - Explaining the German diffusion of renewable energy technology. Energy Policy 34, 256-276 (2006).

24. Steffen, B. The importance of project finance for renewable energy projects. Energy Econ. 69, 280-294 (2018).

25. Gatti, S. Project finance in theory and practice : designing, structuring, and financing private and public projects. (Academic Press, 2013).

26. Damodaran, A. Equity Risk Premiums (ERP): Determinants, Estimation and Implications The 2016 Edition. SSRN Electron. J. (2016).

27. Eisenhardt, K. M. \& Graebner, M. E. Theory Building from Cases: Opportunities and Challenges. Acad. Manag. J. 50, 25-32 (2007).

28. Jiménez, G., Ongena, S., Peydró, J. L. \& Saurina, J. Credit supply and monetary policy: Identifying the bank balancesheet channel with loan applications. Am. Econ. Rev. 102, 2301-2326 (2012).

29. Borio, C. \& Zhu, H. Capital regulation, risk-taking and monetary policy: A missing link in the transmission mechanism? J. Financ. Stab. 8, 236-251 (2012).

30. Altunbas, Y., Gambacorta, L. \& Marques-lbanez, D. Does Monetary Policy Affect Bank Risk? Int. J. Cent. Bank. (2014).

31. Huenteler, J., Schmidt, T. S., Ossenbrink, J. \& Hoffmann, V. H. Technology life-cycles in the energy sector Technological characteristics and the role of deployment for innovation. Technol. Forecast. Soc. Change 104, 102-121 (2016).

32. Pahle, M. \& Schweizerhof, H. Time for Tough Love: Towards Gradual Risk Transfer to Renewables in Germany. Econ. Energy Environ. Policy 5, (2016).

33. May, N. G. \& Neuhoff, K. Financing Power: Impacts of Energy Policies in Changing Regulatory Environments. DIW Berlin Discuss. Pap. No. 1684 (2017).

34. Neuhoff, K. Large-Scale Deployment of Renewables for Electricity Generation. Oxford Rev. Econ. Policy 21, 88-110 (2005).

35. Nelson, D. in Renewable Energy Finance: Powering the Future (ed. Donovan, C. W.) 273-305 (Imperial College Press, 2015).

36. Yelle, L. E. The learning curve: historical review and comprehensive survey. Decis. Sci. 10, 302-328 (1979).

37. Qiu, Y. \& Anadon, L. D. The price of wind power in China during its expansion: Technology adoption, learning-bydoing, economies of scale, and manufacturing localization. Energy Econ. 34, 772-785 (2012).

38. Rubin, E. S., Azevedo, I. M. L., Jaramillo, P. \& Yeh, S. A review of learning rates for electricity supply technologies. Energy Policy 86, 198-218 (2015).

39. Wright, T. P. Factors Affecting the Cost of Airplanes. J. Aeronaut. Sci. 3, 122-128 (1936).

40. Elton, E. J., Gruber, M. J., Agrawal, D. \& Mann, C. Explaining the rate spread on corporate bonds. J. Finance 56, 247277 (2001).

41. IRENA. Renewable Power Generation Costs in 2017. (2018).

42. Lehmann, P. \& Söderholm, P. Can Technology-Specific Deployment Policies Be Cost-Effective? The Case of Renewable Energy Support Schemes. Environ. Resour. Econ. 1-31 (2017). 
43. Geddes, A., Schmidt, T. S. \& Steffen, B. The multiple roles of state investment banks in low-carbon energy finance: An analysis of Australia, the UK and Germany. Energy Policy 115, 158-170 (2018).

44. Tietjen, O., Pahle, M. \& Fuss, S. Investment risks in power generation: A comparison of fossil fuel and renewable energy dominated markets. Energy Econ. 58, 174-185 (2016).

45. Campiglio, E. et al. Climate change challenges for central banks and financial regulators. Nat. Clim. Chang. 8, 462468 (2018).

46. IRENA. Renewable capacity statistics 2017. (2017).

47. Trend Research. Definition und Marktanalyse von Bürgerenergie in Deutschland. (2013).

48. Chatham House. Chatham House Rule. (2002). Available at: https://www.chathamhouse.org/about/chatham-houserule. (Accessed: 28th February 2018)

49. Hoppmann, J., Peters, M., Schneider, M. \& Hoffmann, V. H. The two faces of market support-How deployment policies affect technological exploration and exploitation in the solar photovoltaic industry. Res. Policy 42, 989-1003 (2013).

50. BNEF. Asset database. Bloomberg (2017).

51. European Central Bank. Long-term interest rate statistics for EU Member States. (2018). Available at: https://www.ecb.europa.eu/stats/financial_markets_and_interest_rates/long_term_interest_rates/html/index.en.html. (Accessed: 1st March 2018)

52. Frankfurt School-UNEP \& BNEF. Global Trends in Renewable Energy Investment 2017. (2017).

53. Eisenhardt, K. M. Building Theories from Case Study Research. Acad. Manag. Rev. 14, 532-550 (1989).

54. OECD. Statutory corporate income tax rate. 2018 Available at: http://stats.oecd.org/index.aspx?DataSetCode=TABLE_II1. (Accessed: 1st March 2018)

55. Walker, D. \& Myrick, F. Grounded theory: An exploration of process and procedure. Qual. Health Res. 16, 547-559 (2006).

56. Glaser, B. G. Emergence vs forcing : basics of grounded theory analysis. (Sociology Press, 1992).

57. Nordhaus, W. D. The perils of the learning model for modeling endogenous thechnological change. Energy J. 35, 1-14 (2014)

58. Lindman, Å. \& Söderholm, P. Wind power learning rates: A conceptual review and meta-analysis. Energy Econ. 34, 754-761 (2012).

59. Miles, I. Patterns of innovation in service industries. IBM Syst. J. 47, 115-128 (2008).

60. Elche-Hotelano, D. Sources of knowledge, investments and appropriability as determinants of innovation: An empirical study in service firms. Innov. Manag. Policy Pract. 13, 224-239 (2011).

61. Huenteler, J., Niebuhr, C. \& Schmidt, T. S. The effect of local and global learning on the cost of renewable energy in developing countries. J. Clean. Prod. 128, 6-21 (2016).

62. Wirth, H. Aktuelle Fakten zur Photovoltaik in Deutschland. Fraunhofer-Institut für Solare Energiesysteme ISE (2018).

63. Durstewitz, M. et al. Windenergie Report Deutschland 2016. 116 (2017).

64. Bächler, M. Technical Risk Management during O \& M of PV Plants. e.on Present. (2016). 


\section{Supplementary Information}

\section{Supplementary Note 1: Key terms of project finance}

In project finance, each project is a separate legal entity, set up for the project's lifetime, often called a special purpose vehicle (SPV). The project sponsors hold equity in the SPV, and banks typically provide loans (i.e., debt) to the SPV. In this paper, we call both project sponsors and banks investors. The expected returns to project sponsors are called cost of equity, and the interest to be paid on the loans is called cost of debt. The relative shares of debt and equity in a project define the leverage or capital structure of the SPV. Loan providers usually have no recourse beyond the project, which means the project's risk profile translates directly to the cost of debt. Consequently, the cash flows generated by the SPV must cover operating costs and the debt service (i.e., capital repayment and interest) ${ }^{1}$. Any remaining cash flows go to the project sponsors and constitute their return on the investment. Therefore, equity investors also are concerned about a project's ability to service outstanding debt. The common metric to assess debt service is the debt service coverage ratio (DSCR), which serves as a direct measure of project risk (see Supplementary Table 1). Moreover, the SPV's capital structure usually also is an indication of project risk because more debt increases the debt service (just as a higher cost of debt does). As per convention, we analyse the financing conditions of SPVs at the beginning of projects, i.e., the point when investors make their investment decisions. Contrary to corporate finance, project finance directly ties the cost of capital to project risk ${ }^{1,2}-$ providing a unique setting in which to study the dynamics of renewable energy financing conditions. Because project finance conditions are not quoted publicly, it is necessary to elicit data from renewable energy investment professionals. 


\section{Supplementary Figures}

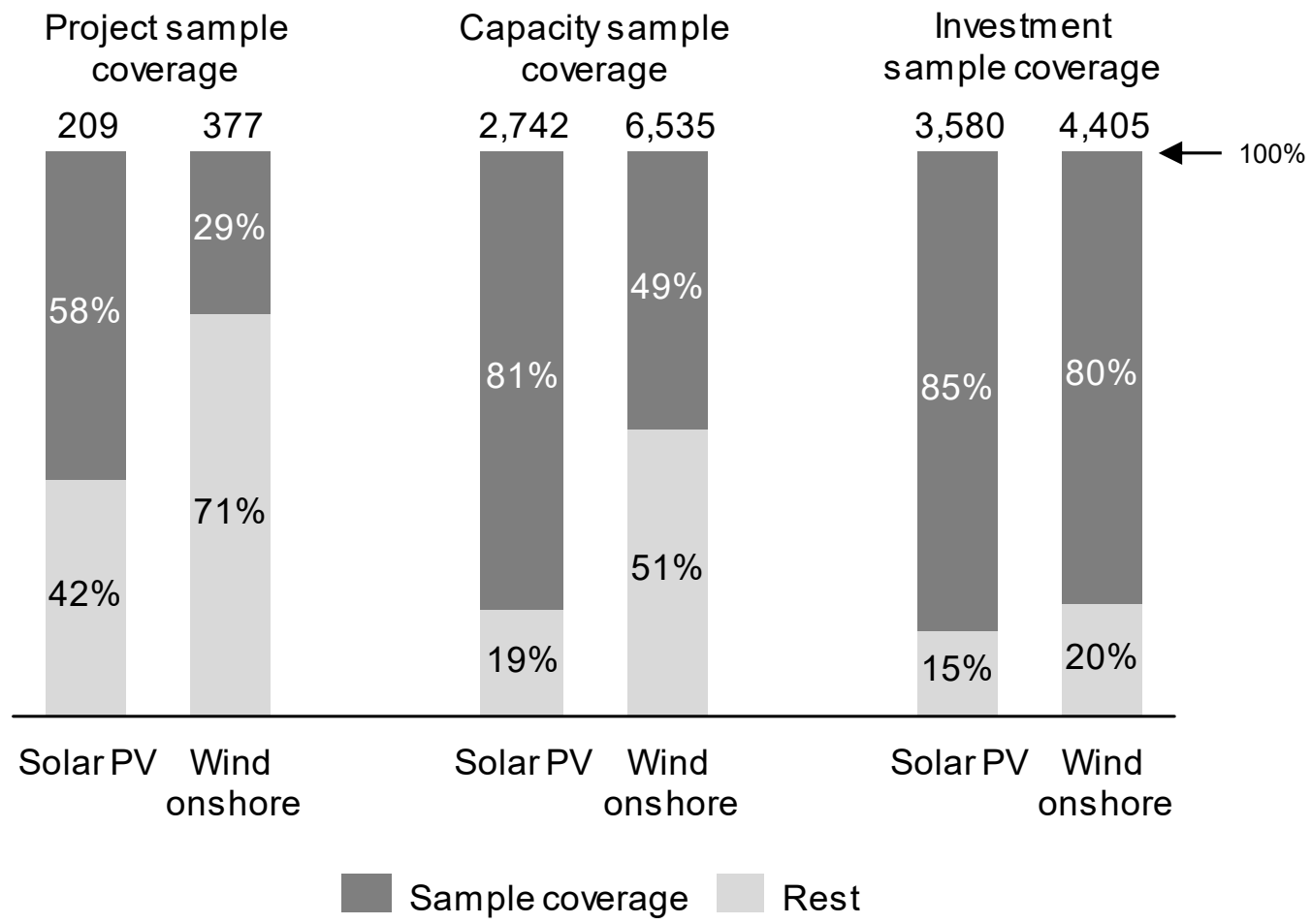

Supplementary Figure 1: Market share of our data providers. Sample coverage is shown with regards to all deals recorded in the BNEF asset database between 2000 and 2017. We calculate the sample coverage over the total of deals, where a lead debt arranger is specified. BNEF provides at least one lead debt arranger for $45 \%$ of solar PV investments and $42 \%$ of wind onshore investments. 


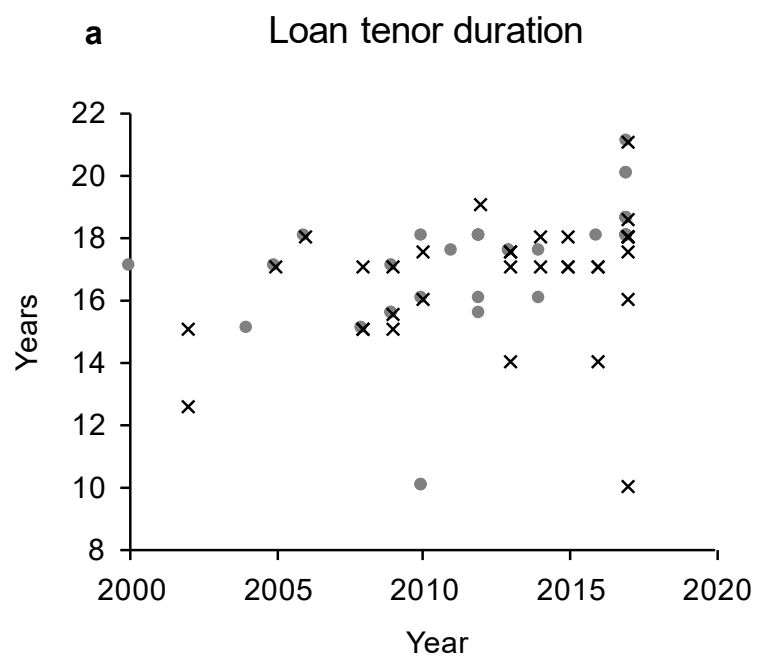

b

Leverage
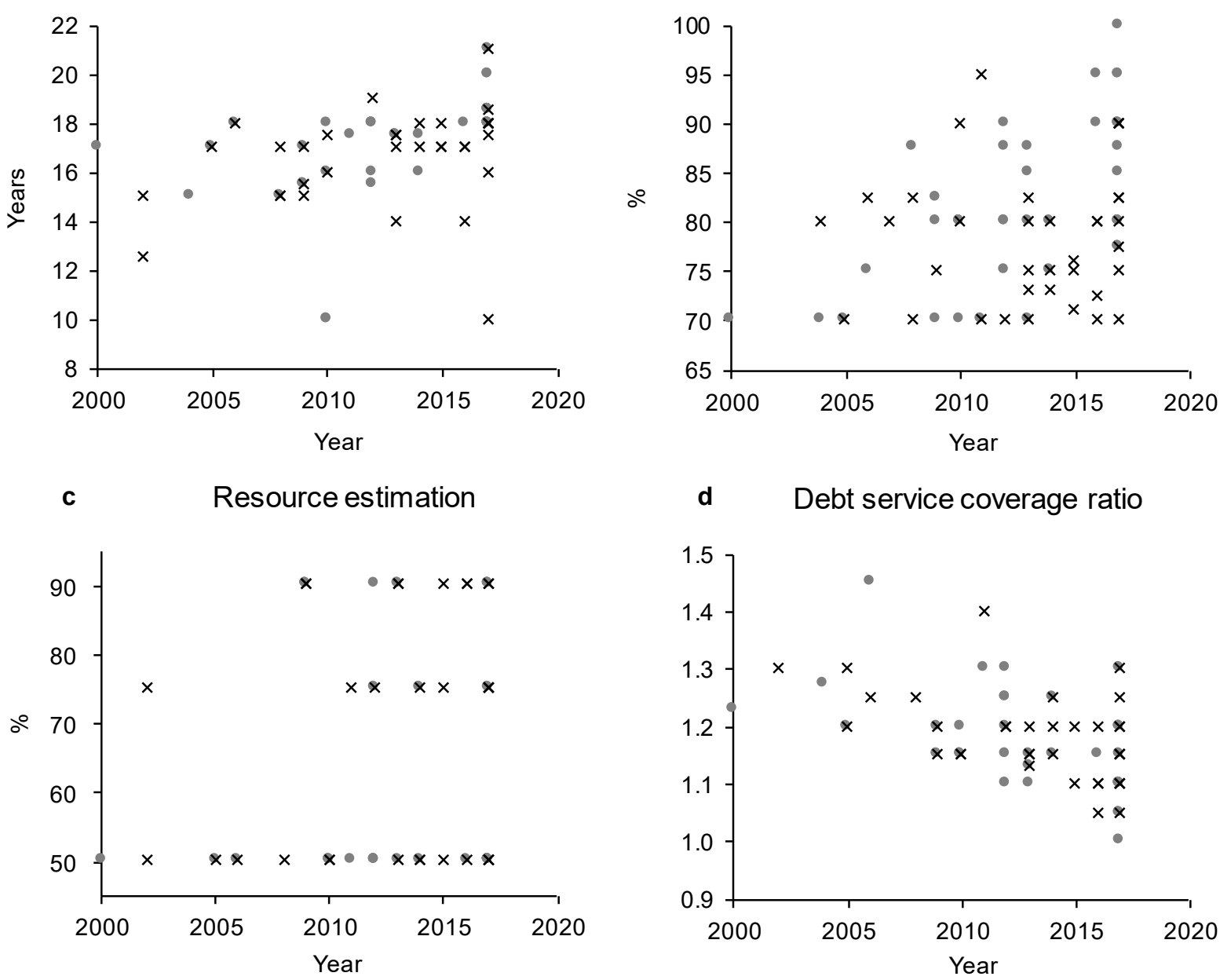

d Debt service coverage ratio

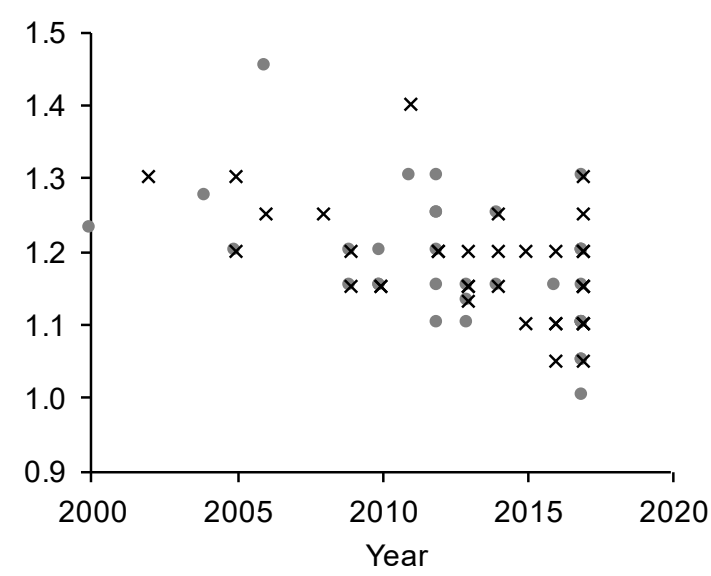

Solar PV $\times$ Wind onshore

Supplementary Figure 2: Financial deal characteristics. a, Loan tenors $(N=70)$ increased over time. b, Leverage $(N=74)$ increased for solar PV and remained relatively constant for wind onshore. $\mathbf{c}$, the resource estimation (percentile of the estimated distribution) has remained split between p50 (median) and p90 (risk-averse) for both technologies $(\mathrm{N}=61)$. $\mathbf{d}$, The debt service coverage ratio $(\mathrm{N}=71)$ decreased for both technologies. 
a

10 year German

government bond yield

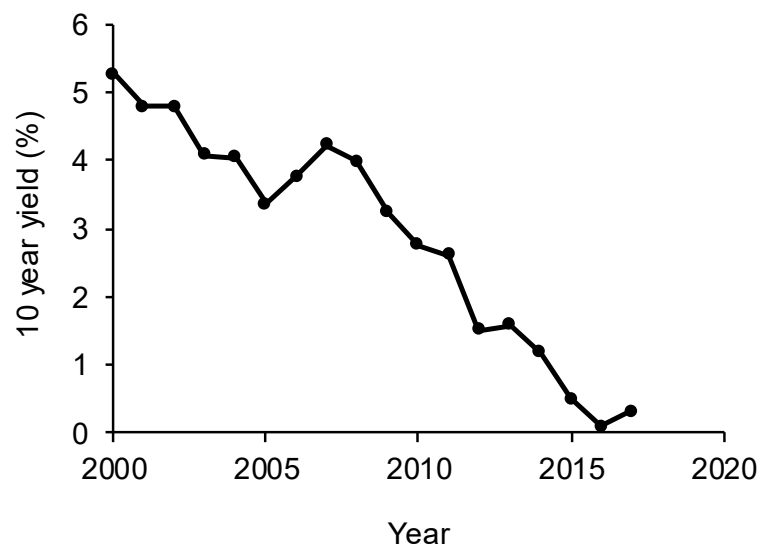

b

Tax rate

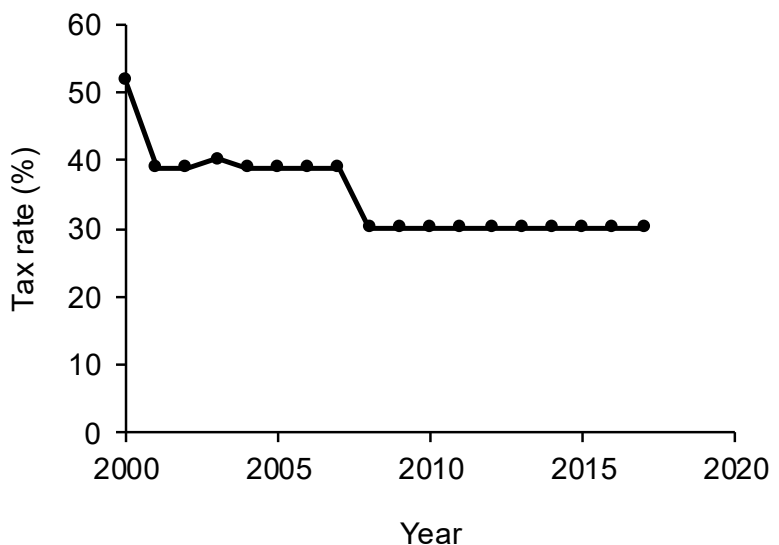

Supplementary Figure 3: Economic variables. Government bond yields decreased from over $5 \%$ to $0.31 \%$ over the period of our sample $(\mathbf{a})^{3}$. The corporate tax rate has fallen from $52 \%$ to $30 \%$, making debt comparatively more expensive $(\mathbf{b})^{4}$.

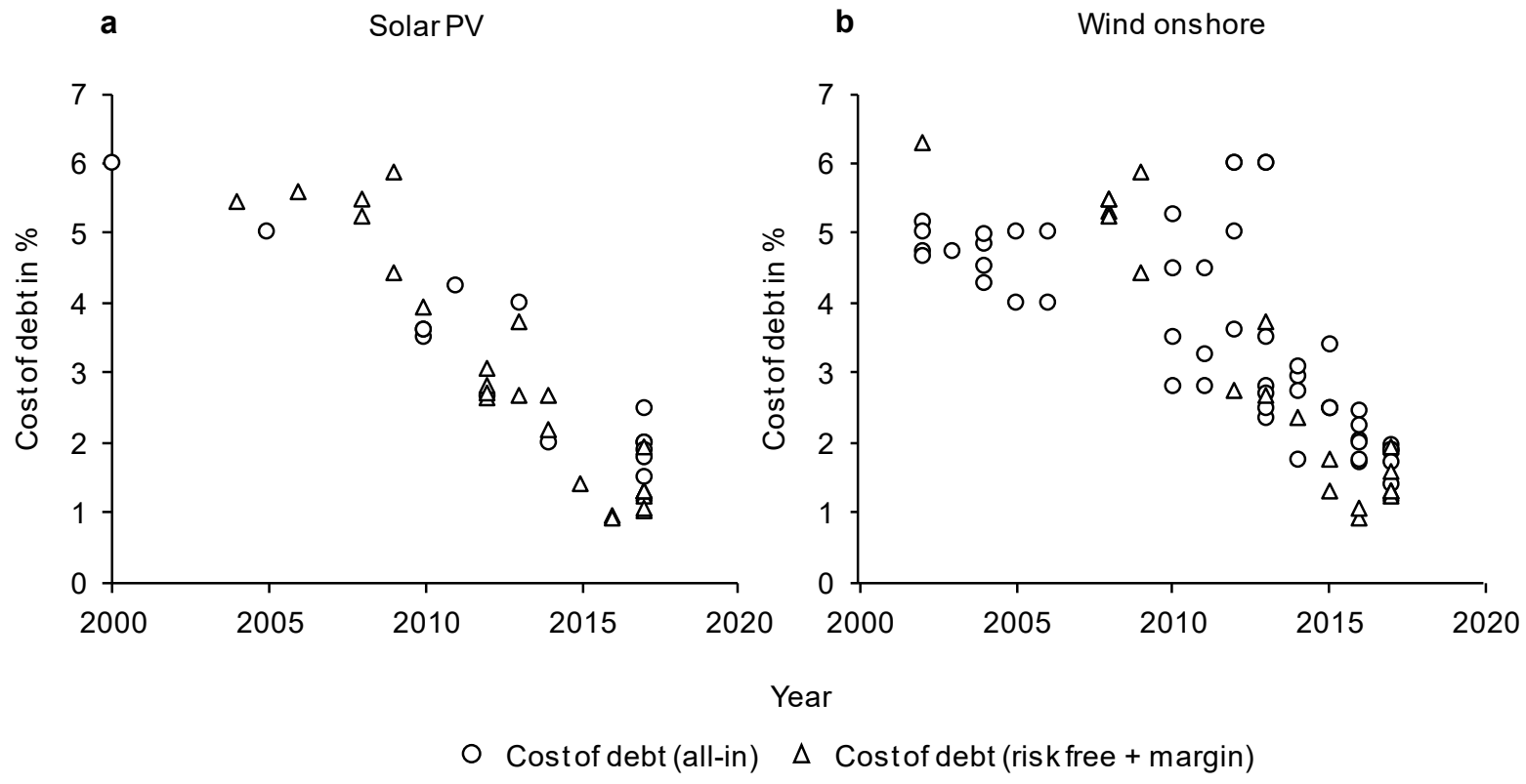

Supplementary Figure 4: Data validity check comparing the reported all-in cost of debt vs. 'synthetic' cost of debt resulting from reported debt margins adding the yield of a 10 year German government bond (risk free). a, Solar PV projects ( $\mathrm{N}=42)$, of which 15 all-in and 27 'synthetic'. $\mathbf{b}$, Wind onshore projects $(\mathrm{N}=73)$, of which 51 all-in and 22 'synthetic'. 

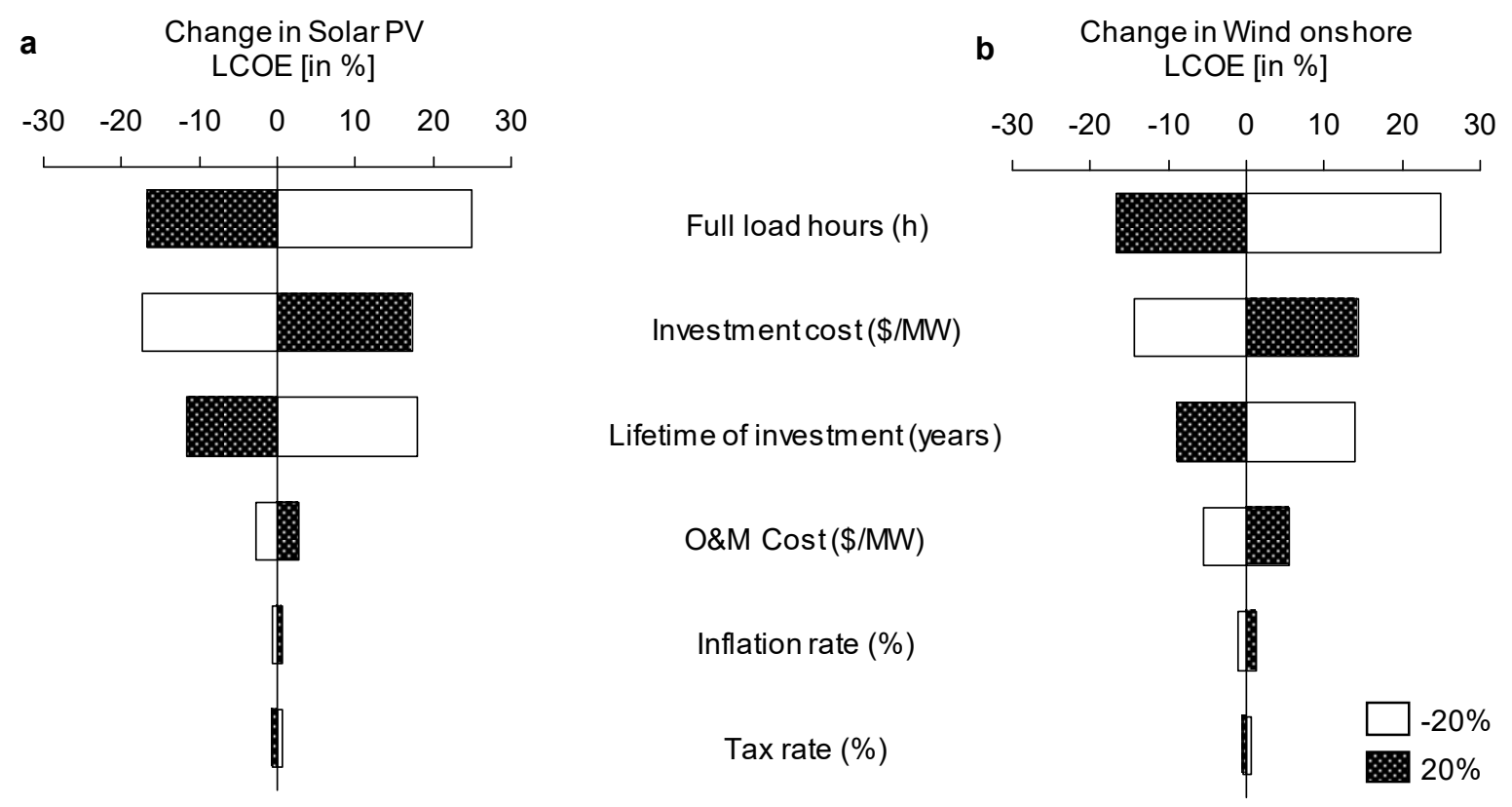

Supplementary Figure 5: LCOE sensitivity analysis for solar PV (a) and wind onshore (b). The figure depicts percent changes in the LCOE for both technologies given a $+/-20 \%$ change in one of the LCOE variables (all other variables stay remain constant). See Table 4 in the Supplementary Information for the values. 


\section{Supplementary Tables}

Supplementary Table 1: Definitions of financial terms.

\begin{tabular}{|c|c|}
\hline Term & Definition \\
\hline $\begin{array}{l}\text { Capital expenditure } \\
\text { (CAPEX) }\end{array}$ & The initial expenditure (i.e. investment) into the RET generation asset. \\
\hline Cost of capital (CoC) & $\begin{array}{l}\text { The weighted average cost of capital (often denoted WACC) of a project, } \\
\text { calculated according to Equation (2). }\end{array}$ \\
\hline Cost of debt & Interest payments on the debt raised to finance a project. \\
\hline Cost of equity & Dividends payments (i.e. return) to project shareholders. \\
\hline Debt margin & $\begin{array}{l}\text { The project specific margin on top of the refinancing rate of the debt } \\
\text { provider (e.g., bank). }\end{array}$ \\
\hline $\begin{array}{l}\text { Debt service } \\
\text { coverage ratio } \\
\text { (DSCR) }\end{array}$ & $\begin{array}{l}\text { A measure of project cash flows available to pay debt obligations, namely } \\
\text { the principal repayment and interest rate payments. }\end{array}$ \\
\hline Financing conditions & $\begin{array}{l}\text { The wider financial conditions of a project including among others CoC, } \\
\text { DSCR, and loan tenor. }\end{array}$ \\
\hline Financing cost & $\begin{array}{l}\text { The total cost of capital service, including debt service (i.e. principal } \\
\text { repayment and interest rate payments) and returns to equity. }\end{array}$ \\
\hline Investment cost & $\begin{array}{l}\text { The initial investment cost of a RET generation. Used interchangeably with } \\
\text { capital expenditure. }\end{array}$ \\
\hline Leverage & $\begin{array}{l}\text { The project capital structure, i.e. the share of debt of the total investment } \\
\text { sum. }\end{array}$ \\
\hline Loan tenor & The time period for repayment of the loan. \\
\hline $\begin{array}{l}\text { Operating } \\
\text { expenditure (OPEX) }\end{array}$ & $\begin{array}{l}\text { Expenditures to operate the RET generation assets, occurring throughout } \\
\text { the asset lifetime (if operated). }\end{array}$ \\
\hline$P$ value & $\begin{array}{l}\text { The percentile value of the distribution of solar irradiation or wind speed } \\
\text { predictions used for project assessment. Calculating project returns on a } \\
\text { p90 value means to take the } 90^{\text {th }} \text { percentile of the predicted distribution and } \\
\text { represents a more conservative approach than for example p50 (median). }\end{array}$ \\
\hline
\end{tabular}

Supplementary Table 2: Summary statistics. Counting all project where we have a value for at least one of the following variables: Cost of debt, cost of equity, leverage, cost of capital, loan tenor, and DSCR, our sample covers 48 solar PV and 85 wind onshore projects between 2000 and $2017(N=133)$. If we limit the sample to projects for which we have data on the cost of capital only (cost of debt, cost of equity or cost of capital), our sample includes 43 solar $P V$ and 78 wind onshore projects $(N=121)$.

\begin{tabular}{l|rr|rrr|} 
& $\mathrm{N}$ & Mean & Std. Dev. & Min & \multicolumn{1}{c|}{ Max } \\
\hline $\mathrm{K}_{\mathrm{D}}$ & 112 & 3.18 & 1.57 & 0.89 & 6.28 \\
$\mathrm{~K}_{\mathrm{E}}$ & 66 & 7.07 & 2.13 & 3.25 & 14 \\
Leverage (debt share) & 74 & 80 & 7.75 & 70 & 100 \\
Debt margin & 49 & 1.25 & 0.43 & 0.7 & 2.65 \\
Cost of capital & 57 & 3.20 & 1.59 & 0.59 & 9.50 \\
Loan tenor & 70 & 16.89 & 2.11 & 10 & 21 \\
DSCR & 71 & 1.18 & 0.08 & 1 & 1.45
\end{tabular}


Supplementary Table 3: Full interview sample $(N=41)$

\begin{tabular}{|c|c|c|c|c|c|c|c|}
\hline ID & $\begin{array}{l}\text { Interview } \\
\text { type }\end{array}$ & $\begin{array}{l}\text { Current } \\
\text { organisation }\end{array}$ & Current position & Based in & $\begin{array}{l}\text { RET } \\
\text { investment } \\
\text { experience } \\
\text { (years) }\end{array}$ & Sex & $\begin{array}{l}\text { Age } \\
\text { range }\end{array}$ \\
\hline 1 & Structured & Debt provider & $\begin{array}{l}\text { Head of Division Energy \& } \\
\text { Utilities }\end{array}$ & Germany & 12 & $\mathrm{M}$ & $25-45$ \\
\hline 2 & Structured & Debt provider & $\begin{array}{l}\text { Vice President } \\
\text { Associate Director Project }\end{array}$ & Germany & 28 & $M$ & $45-65$ \\
\hline 3 & Structured & Debt provider & $\begin{array}{l}\text { Finance \& Capital Advisory } \\
\text { Associate Director } \\
\text { Infrastructure \& Power }\end{array}$ & Germany & 7 & $M$ & $25-45$ \\
\hline 4 & Structured & Debt provider & $\begin{array}{l}\text { Project Finance } \\
\text { Executive Director Project } \\
\text { Finance Renewable }\end{array}$ & Germany & 9 & $M$ & $25-45$ \\
\hline 5 & Structured & Debt provider & $\begin{array}{l}\text { Energies } \\
\text { Associate Director Global }\end{array}$ & $\begin{array}{l}\text { Germany } \\
\text { United }\end{array}$ & 21 & $\mathrm{M}$ & $45-65$ \\
\hline 6 & Structured & Debt provider & Infrastructure Debt & Kingdom & 5 & $\mathrm{~F}$ & $25-45$ \\
\hline 7 & Structured & Debt provider & Head Renewable Energies & Germany & 27 & M & $45-65$ \\
\hline 8 & Structured & Debt provider & $\begin{array}{l}\text { Project Finance Analyst } \\
\text { Vice President Corporates } \\
\& \text { Small Business Project }\end{array}$ & Germany & 11 & M & $25-45$ \\
\hline 9 & Structured & Debt provider & $\begin{array}{l}\text { Finance } \\
\text { Director Structured Finance }\end{array}$ & $\begin{array}{l}\text { Germany } \\
\text { The }\end{array}$ & 11 & M & $45-65$ \\
\hline 10 & Structured & Debt provider & $\begin{array}{l}\text { Power \& Renewables } \\
\text { Director Structured Finance } \\
\text { Utilities, Power \& }\end{array}$ & $\begin{array}{l}\text { Netherlands } \\
\text { The }\end{array}$ & 11 & M & $45-65$ \\
\hline 11 & Structured & Debt provider & $\begin{array}{l}\text { Renewables } \\
\text { Senior Manager Structured } \\
\text { Finance Renewable }\end{array}$ & Netherlands & 11 & $M$ & $25-45$ \\
\hline 12 & Structured & Debt provider & $\begin{array}{l}\text { Energy } \\
\text { Director Project \& }\end{array}$ & Germany & 19 & M & $45-65$ \\
\hline 13 & Structured & Debt provider & Power and Renewables & $\begin{array}{l}\text { Italy } \\
\text { The }\end{array}$ & 11 & $\mathrm{~F}$ & $25-45$ \\
\hline 14 & Structured & Debt provider & $\begin{array}{l}\text { Director Corporate Strategy } \\
\text { Head of Renewable }\end{array}$ & Netherlands & 19 & M & $40-65$ \\
\hline 15 & Structured & Debt provider & $\begin{array}{l}\text { Energies } \\
\text { Head of Project Finance } \\
\text { Origination Renewable }\end{array}$ & Germany & 23 & $M$ & $40-65$ \\
\hline 16 & Structured & Debt provider & $\begin{array}{l}\text { Energies } \\
\text { Managing Director Project }\end{array}$ & $\begin{array}{l}\text { Germany } \\
\text { United }\end{array}$ & 8 & M & $45-65$ \\
\hline 17 & Structured & $\begin{array}{l}\text { Debt provider } \\
\text { Equity }\end{array}$ & \& Acquisition Finance & Kingdom & 12 & M & $25-45$ \\
\hline 18 & Structured & $\begin{array}{l}\text { provider* } \\
\text { Equity }\end{array}$ & Head Risk Advisory & Germany & 13 & M & $45-65$ \\
\hline 19 & Structured & $\begin{array}{l}\text { provider* } \\
\text { Equity }\end{array}$ & CEO & Germany & 10 & $\mathrm{M}$ & $45-65$ \\
\hline 20 & Structured & provider $^{*}$ & Founder and CEO & Germany & 5 & M & $25-45$ \\
\hline 21 & Structured & Equity provider & Principal & Switzerland & 5 & M & $25-45$ \\
\hline 22 & Structured & Equity provider & $\begin{array}{l}\text { Partner } \\
\text { Director Infrastructure }\end{array}$ & Switzerland & 9 & M & $45-65$ \\
\hline 23 & Structured & Equity provider & Equity Investment Team & Germany & 12 & M & $45-65$ \\
\hline 24 & Structured & Equity provider & Vice President Renewables & Switzerland & 3 & M & $25-45$ \\
\hline 25 & Structured & Equity provider & $\mathrm{ClO}$ & Germany & 2 & M & $25-45$ \\
\hline 26 & Structured & Equity provider & $\begin{array}{l}\text { CEO } \\
\text { Associate Director Energy }\end{array}$ & Germany & 2 & M & $25-45$ \\
\hline 27 & Structured & Equity provider & \& Cleantech & $\begin{array}{l}\text { France } \\
\text { United }\end{array}$ & 12 & $M$ & $25-45$ \\
\hline 28 & Structured & Equity provider & Associate & Kingdom & 18 & M & $25-45$ \\
\hline 29 & Structured & Public actor & $\begin{array}{l}\text { Head Energy Services } \\
\text { Deputy Head Energy }\end{array}$ & Switzerland & 12 & M & $25-45$ \\
\hline 30 & Structured & Public actor & Management & Switzerland & 3 & $M$ & $25-45$ \\
\hline 31 & Structured & Public actor & CEO & Switzerland & 7 & M & $45-65$ \\
\hline
\end{tabular}




\begin{tabular}{|c|c|c|c|c|c|c|c|}
\hline & & & $\begin{array}{l}\text { Head Portfolio and Asset } \\
\text { Management Renewable }\end{array}$ & & & & \\
\hline 32 & Structured & Public actor & $\begin{array}{l}\text { Energies } \\
\text { Vice President Origination }\end{array}$ & Switzerland & 8 & M & $25-45$ \\
\hline 33 & Structured & Public actor & and Structuring & Germany & 6 & M & $25-45$ \\
\hline 34 & Exploratory & Equity provider & Founding Partner & $\begin{array}{l}\text { Switzerland } \\
\text { United }\end{array}$ & 18 & $\mathrm{~F}$ & $45-65$ \\
\hline 35 & Exploratory & $\begin{array}{l}\text { Equity provider } \\
\text { Equity }\end{array}$ & Investments Director & Kingdom & 12 & M & $25-45$ \\
\hline 36 & Exploratory & provider* $^{*}$ & Head Risk Advisory & Germany & 13 & M & $45-65$ \\
\hline 37 & Exploratory & Equity provider & Partner & Switzerland & 9 & M & $45-65$ \\
\hline 38 & Exploratory & Equity provider & Principal & Switzerland & 5 & M & $25-45$ \\
\hline 39 & Exploratory & $\begin{array}{l}\text { Other (former } \\
\text { researcher) }\end{array}$ & $\begin{array}{l}\text { Head Hybrid Power } \\
\text { Solutions } \\
\text { Senior Investment }\end{array}$ & Germany & 12 & M & $25-45$ \\
\hline 40 & Exploratory & Public actor & Manager & Norway & 11 & M & $45-65$ \\
\hline 41 & Exploratory & Public actor & $\begin{aligned} & \text { Economist } \\
= & \text { Acts as advisor for } \epsilon\end{aligned}$ & $\begin{array}{l}\text { Luxemburg } \\
\text { nvestors }\end{array}$ & 15 & $M$ & $25-45$ \\
\hline
\end{tabular}

Note: For age, only ranges given to protect anonymity of interviewees

Supplementary Table 4: LCOE model parameters

\begin{tabular}{|c|c|c|c|c|}
\hline \multirow[b]{2}{*}{ Parameters } & \multicolumn{2}{|c|}{ Solar PV } & \multicolumn{2}{|c|}{ Wind onshore } \\
\hline & $2000-05$ & 2017 & $2000-05$ & 2017 \\
\hline Inflation & $2 \%$ & $2 \%$ & $2 \%$ & $2 \%$ \\
\hline Full load hours p.a. & 1051 & 1051 & 1500 & 2716 \\
\hline Investment cost US $\$ \mathrm{MW}^{-1}$ (CAPEX) & $6.37 \mathrm{~m}$ & $1.05 \mathrm{~m}$ & $1.60 \mathrm{~m}$ & $2.00 \mathrm{~m}$ \\
\hline $\mathrm{MW}^{-1} \mathrm{year}^{-1}(\mathrm{OPEX})^{6,8}$ & 8'000 & $8^{\prime} 000$ & $38^{\prime} 000$ & $38^{\prime} 000$ \\
\hline Asset lifetime & 20 & 20 & 20 & 20 \\
\hline Cost of capital & $5.1 \%$ & $1.6 \%$ & $4.5 \%$ & $1.9 \%$ \\
\hline
\end{tabular}


Supplementary Table 5: Solar PV experience rate estimation and robustness checks. All regressions are calculated using OLS with robust standard errors and all variables are in log. For each specification, we show a version without and a version with investor fixed effects. InvUNEP denotes the cumulative global investment data from UN Environment (columns 1 and 2), InvEU denotes cumulative European investment (columns 3 and 4), InvBNEFxIRENA denotes the alternative measure for cumulative global investment using data from BNEF on investment cost per MW and data from IRENA on capacity (columns 5 and 6 ). The resulting minimum and maximum experience rates are shown in Supplementary Table 7. For details on the variables, see Methods.

\begin{tabular}{|c|c|c|c|c|c|c|c|c|c|c|c|c|c|c|c|c|c|c|}
\hline VARIABLES & (1) & (2) & $\begin{array}{l}\text { (3) } \\
\text { Log(debt }\end{array}$ & $\begin{array}{r}(4) \\
\text { nargin) } \\
\end{array}$ & (5) & (6) & (1) & (2) & $\begin{array}{l}\text { (3) } \\
\log (d \mathrm{~d}\end{array}$ & ${ }^{(4-1)}$ & (5) & (6) & (1) & (2) & $\begin{array}{l}3) \\
\text { Log(loa }\end{array}$ & $\begin{array}{r}\quad(4) \\
\text { tenor) } \\
\end{array}$ & (5) & (6) \\
\hline Log(InvUNEP) & $\begin{array}{c}-0.162^{\star \star \star} \\
(0.0532)\end{array}$ & $\begin{array}{c}-0.149^{\star \star \star} \\
(0.0362)\end{array}$ & & & & & $\begin{array}{l}-0.209^{\star \star \star *} \\
(0.0744)\end{array}$ & $\begin{array}{c}-0.257^{\star \star \star} \\
(0.0638)\end{array}$ & & & & & $\begin{array}{l}0.0376^{\star *} \\
(0.0170)\end{array}$ & $\begin{array}{l}0.0585^{* *} \\
(0.0224)\end{array}$ & & & & \\
\hline Log(InvEU) & & & $\begin{array}{l}-0.155^{\star *} \\
(0.0567)\end{array}$ & $\begin{array}{c}-0.147^{* * *} \\
(0.0451)\end{array}$ & & & & & $\begin{array}{c}-0.186^{* *} \\
(0.0699)\end{array}$ & $\begin{array}{c}-0.215^{\star * *} \\
(0.0543)\end{array}$ & & & & & $\begin{array}{l}0.0276^{*} \\
(0.0152)\end{array}$ & $\begin{array}{l}0.0479^{\star *} \\
(0.0200)\end{array}$ & & \\
\hline Log(InvBNEFXIRENA) & & & & & $\begin{array}{l}-0.164^{* * *} \\
(0.0511)\end{array}$ & $\begin{array}{l}-0.151^{* \star *} \\
(0.0356)\end{array}$ & & & & & $\begin{array}{l}-0.226^{* * *} \\
(0.0759)\end{array}$ & $\begin{array}{l}-0.273^{\star \star \star *} \\
(0.0609)\end{array}$ & & & & & $\begin{array}{l}0.0403^{* *} \\
(0.0171)\end{array}$ & $\begin{array}{l}0.0623^{* *} \\
(0.0226)\end{array}$ \\
\hline Constant & $\begin{array}{c}1.194^{* \star *} \\
(0.350)\end{array}$ & $\begin{array}{c}1.693^{* * *} \\
(0.239)\end{array}$ & $\begin{array}{c}2.042^{\star * *} \\
(0.690)\end{array}$ & $\begin{array}{c}2.532^{\star \star \star} \\
(0.556)\end{array}$ & $\begin{array}{c}1.162^{\star * *} \\
(0.322)\end{array}$ & $\begin{array}{l}1.662^{* * *} \\
(0.227)\end{array}$ & $\begin{array}{l}-0.588 \\
(0.429)\end{array}$ & $\begin{array}{l}-0.206 \\
(0.497)\end{array}$ & $\begin{array}{c}0.335 \\
(0.804)\end{array}$ & $\begin{array}{c}0.746 \\
(0.749)\end{array}$ & $\begin{array}{l}-0.539 \\
(0.416)\end{array}$ & $\begin{array}{l}-0.163 \\
(0.468)\end{array}$ & $\begin{array}{c}2.598^{* * *} \\
(0.117)\end{array}$ & $\begin{array}{c}2.434^{* * *} \\
(0.157)\end{array}$ & $\begin{array}{c}2.501^{* * *} \\
(0.187)\end{array}$ & $\begin{array}{c}2.231^{\star * *} \\
(0.256)\end{array}$ & $\begin{array}{c}2.591^{* * *} \\
(0.114)\end{array}$ & $\begin{array}{c}2.423^{* * *} \\
(0.152)\end{array}$ \\
\hline Investor fixed effects & no & yes & no & yes & no & yes & no & yes & no & yes & no & yes & no & yes & no & yes & no & yes \\
\hline Observations & 27 & 27 & 27 & 27 & 27 & 27 & 35 & 35 & 35 & 35 & 35 & 35 & 36 & 36 & 36 & 36 & 36 & 36 \\
\hline R-squared & 0.287 & 0.850 & 0.204 & 0.801 & 0.284 & 0.847 & 0.162 & 0.696 & 0.115 & 0.634 & 0.167 & 0.697 & 0.104 & 0.398 & 0.050 & 0.319 & 0.107 & 0.402 \\
\hline
\end{tabular}




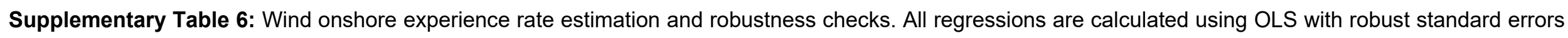

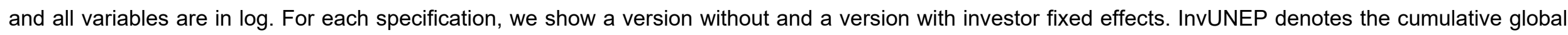

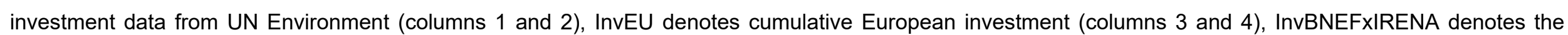

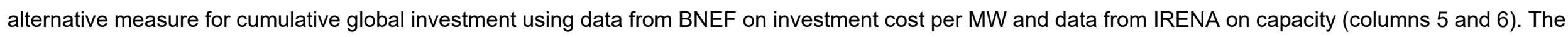
resulting minimum and maximum experience rates are shown in Supplementary Table 7. For details on the variables, see Methods.

\begin{tabular}{|c|c|c|c|c|c|c|c|c|c|c|c|c|c|c|c|c|c|c|}
\hline VARIABLES & (1) & (2) & $\begin{array}{l}\text { (3) } \\
\text { Log(deb } \\
\end{array}$ & $\begin{array}{r}(4) \\
\text { margin) } \\
\end{array}$ & (5) & (6) & (1) & (2) & $\begin{array}{l}\text { (3) } \\
\text { Log(c }\end{array}$ & $\begin{array}{c}(4) \\
\mathrm{cr}-1)\end{array}$ & (5) & (6) & (1) & (2) & \multicolumn{2}{|c|}{$\begin{array}{ll}(3) & (4) \\
\text { Log(loan tenor) }\end{array}$} & (5) & (6) \\
\hline Log(IIUUNEP) & $\begin{array}{l}-0.164^{* *} \\
(0.0633)\end{array}$ & $\begin{array}{c}-0.162^{* * *} \\
(0.0472)\end{array}$ & & & & & $\begin{array}{c}-0.261^{* \star *} \\
(0.0594)\end{array}$ & $\begin{array}{l}-0.283^{* \star *} \\
(0.0936)\end{array}$ & & & & & $\begin{array}{l}0.0430^{*} \\
(0.0253)\end{array}$ & $\begin{array}{l}0.0532^{* *} \\
(0.0254)\end{array}$ & & & & \\
\hline Log(InvEU) & & & $\begin{array}{l}-0.254^{* *} \\
(0.0982)\end{array}$ & $\begin{array}{c}-0.254^{\star \star *} \\
(0.0750)\end{array}$ & & & & & $\begin{array}{l}-0.423^{* * *} \\
(0.0992)\end{array}$ & $\begin{array}{c}-0.459^{* *} \\
(0.161)\end{array}$ & & & & & $\begin{array}{l}0.0688^{*} \\
(0.0401)\end{array}$ & $\begin{array}{l}0.0866^{* *} \\
(0.0377)\end{array}$ & & \\
\hline $\log (\ln \cup B N E F \times \mid R E N A)$ & & & & & $\begin{array}{l}-0.182^{\star \star \star} \\
(0.0638)\end{array}$ & $\begin{array}{l}-0.178^{\star \star \star} \\
(0.0423)\end{array}$ & & & & & $\begin{array}{l}-0.280^{\star * *} \\
(0.0646)\end{array}$ & $\begin{array}{l}-0.310^{\star \star *} \\
(0.0964)\end{array}$ & & & & & $\begin{array}{c}0.0449 \\
(0.0280)\end{array}$ & $\begin{array}{l}0.0567^{*} \\
(0.0288)\end{array}$ \\
\hline Constant & $\begin{array}{c}1.250^{* * *} \\
(0.416)\end{array}$ & $\begin{array}{c}1.789^{* * *} \\
(0.317)\end{array}$ & $\begin{array}{l}3.272^{\star *} \\
(1.196)\end{array}$ & $\begin{array}{c}3.819^{* * *} \\
(0.910)\end{array}$ & $\begin{array}{c}1.292^{* * *} \\
(0.392)\end{array}$ & $\begin{array}{c}1.816^{* * *} \\
(0.264)\end{array}$ & $\begin{array}{l}-0.123 \\
(0.344)\end{array}$ & $\begin{array}{r}-0.0273 \\
(0.651)\end{array}$ & $\begin{array}{l}3.315^{* \star *} \\
(1.161)\end{array}$ & $\begin{array}{l}3.703^{*} \\
(1.974)\end{array}$ & $\begin{array}{l}-0.118 \\
(0.350)\end{array}$ & $\begin{array}{l}0.0186 \\
(0.628)\end{array}$ & $\begin{array}{c}2.531 * * * \\
(0.154)\end{array}$ & $\begin{array}{r}2.472^{\star * *} \\
(0.172)\end{array}$ & $\begin{array}{c}1.976^{* \star *} \\
(0.474)\end{array}$ & $\begin{array}{c}1.769^{* * *} \\
(0.464)\end{array}$ & $\begin{array}{c}2.538^{* * *} \\
(0.159)\end{array}$ & $\begin{array}{r}2.473^{* * *} \\
(0.183)\end{array}$ \\
\hline Investor fixed effects & no & yes & no & yes & no & yes & no & yes & no & yes & no & yes & no & yes & no & yes & no & yes \\
\hline Observations & 22 & 22 & 22 & 22 & 22 & 22 & 36 & 36 & 36 & 36 & 36 & 36 & 34 & 34 & 34 & 34 & 34 & 34 \\
\hline R-squared & 0.212 & 0.913 & 0.209 & 0.915 & 0.235 & 0.925 & 0.218 & 0.636 & 0.224 & 0.645 & 0.222 & 0.648 & 0.089 & 0.746 & 0.091 & 0.753 & 0.083 & 0.743 \\
\hline
\end{tabular}


Supplementary Table 7: Experience rate robustness checks. The table indicates minimum and maximum values for the experience rates across all model specifications shown in Supplementary Tables 5 and 6.

\begin{tabular}{l|cc|cc} 
& \multicolumn{2}{|c|}{ Solar PV } & \multicolumn{2}{c}{ Wind onshore } \\
& Min & Max & Min & Max \\
\hline Debt margin & $10 \%$ & $11 \%$ & $11 \%$ & $16 \%$ \\
DSCR & $12 \%$ & $17 \%$ & $17 \%$ & $27 \%$ \\
Loan tenor & $-2 \%$ & $-4 \%$ & $-3 \%$ & $-6 \%$
\end{tabular}




\section{Supplementary References}

1. Gatti, S. Project finance in theory and practice: designing, structuring, and financing private and public projects. (Academic Press, 2013).

2. Steffen, B. The importance of project finance for renewable energy projects. Energy Econ. 69, 280-294 (2018).

3. European Central Bank. Long-term interest rate statistics for EU Member States. (2018).

4. OECD. Statutory corporate income tax rate. (2018).

5. $\quad$ Wirth, H. Aktuelle Fakten zur Photovoltaik in Deutschland. (2018).

6. Durstewitz, M. et al. Windenergie Report Deutschland 2016. (Fraunhofer Verlag, 2017).

7. BNEF. Asset database. Bloomberg (2017).

8. Bächler, M. Technical Risk Management during O \& M of PV Plants. (2016). 